DEUIFD L / 2019, ss. 61-97.

\title{
İSLAM İKTİSAT DÜŞÜNCESİNDE YOKSULLUK PROBLEMİ
}

Ramazan KORKUT*

ÖZ

İktisadi açıdan zenginlik karşısında yoksulluk olgusu genelde dünyanın, özelde İslam dünyasının ortak sorunlarından biridir. Yoksulluğun birey, toplum ve devlet bazında boyutları bulunmakta ve çeşitli sorunlara zemin hazırlayabilmektedir. $\mathrm{Bu}$ nedenle sebep, sonuç ve çözüm yöntemleri bakımından ele alınması gereken önemli bir olgudur. İslam iktisadı esas aldığı dini ve insani değerlerle bu sorunu çözmeyi hedeflemektedir. Zenginliği yoksulluğa karşı dini/insani bir paylaşım aracına dönüştürmektedir. Maslahat kapsamında ticarete, tarıma, hayvancilığa, sanayileşmeye, istihdam alanı oluşturmaya ve emeği esas alarak çalışmaya teşvik etmektedir. Öte yandan özel mülkiyet ve paylaşım dengesi kurarak sosyal adaleti sağlamaya çalışmaktadır. Yoksulluğa karşı dini, hukuki ve ahlaki bir bütünlük içinde önlem almaktadır. İnsan1, insan onurunu ve toplumu yoksulluğun muhtemel zararlarından korumaktadır. Makalemizde fakirlik/yoksulluk problemi tanım, sebep ve sonuçları bakımından ele alınmakta, İslam iktisat düşüncesinin yoksulluğa yaklaşımı ve bu sorun karşısında aldığ dini/insani tedbirler üzerinde durulmaktadır.

Anahtar Kelimeler: İslam, İktisat, Fakirlik/Yoksulluk, Problem.

\section{POVERTY PROBLEM IN ISLAMIC ECONOMIC THOUGHT}

\section{ABSTRACT}

The problem of poverty in the face of economic wealth is one of the common problems of the world in general and of the Islamic world in particular. Poverty is a phenomenon that has dimensions in terms of individual, society and state. İt also can pave the way for various problems in this context. Therefore the phenomenon of poverty is an important problem that needs to be addressed in terms of its causes, consequences and solution methods. Islamic economics aims to solve this problem with its religious and human values. It has transformed wealth against poverty into a religious/human sharing tool for the

* Dr. Öğr. Üyesi, Bingöl Üniversitesi İlahiyat Fakültesi, İslam Hukuku Anabilim Dalı, e-mail: rkorkut@bingol.edu.tr, ORCID ID: https://orcid.org/0000-0003-36191622.

Makalenin Hakemlere Gönderiliş Tarihi : :10/10/2019

Makalenin Hakemlerden Geliș Tarihi : : : 17/11/2019 
well-being of mankind. On the other hand it encourages trade, agriculture, animal husbandry, industrialization, creating employment and working on the basis of manual labor against poverty. İt balances private property and sharing against poverty. Religious, legal and moral integrity by taking measures against poverty is trying to resolve this problem. In this article, the phenomenon of poverty is discussed in terms of its definition, causes and consequences, and the approach of Islamic economic thought to poverty and the measures it has taken against this problem are discussed.

Keywords: Islam, Economics, Poverty, Problem.

\section{GİRİŞ}

İslam iktisadının temel amaçlarından biri birey, toplum ve devlet bazında yoksulluğa karşı insan onurunu, aileyi, toplumu ve devleti güvence altına alarak sosyal adaleti sağlamaktır. ${ }^{1}$ İslam iktisadı ekonomik olguların yorumunda kitap ve sünnetin yanı sıra bireysel ve kollektif içtihadı merkeze almaktadır. Buna ek olarak başta iktisat bilimi olmak üzere tasavvuf, ahlak, sosyoloji ve tarih bilimlerinden de yararlanmaktadır. ${ }^{2}$ Bir diğer ifadeyle iktisadi sorunları, bu kapsamda yoksulluk olgusunu disiplinler arası bir yaklaşımla değerlendirmektedir. Yoksulluğu yalnızca ekonomik maddi bir probleme indirgememektedir. Onu itikad, ahlak, ibadet, ekonomi ve hukuk bütünlüğü içinde insani etik değerler çerçevesinde ele almaktadır. Bu probleme karşı kendi mensuplarının yanında tüm insanlı̆̆a ahlaki, hukuki ve insani bir sorumluluk yüklemektedir. ${ }^{3}$

1 Bkz. Seyyid Kutup, İslam'ın Dünya Görüsü, (İstanbul: Arslan Yayınlar1, 1991), 198 212; Muhyiddin Ali Karadaği, el-Medhal ila iktisâdi'l-Islamî, (Beyrut: Daru'l-Beşâiri'lİslamiyye, 2010) 1: 439-442; Ahmet Tabakoğlu, İslami İlimlerde Usul/Metodoloji Meselesi II, (İstanbul: İslami İlimler Araştırma Vakf1, 2005), 250; Muhammed Enes b. Mustafa ez-Zerkâ,, Sünaiyyetu mesâdiri'l-ma'rife fî̀ 'ilmi'l-iktısadi'l-İslamî ve netâicuha'l-menheciyye, (Cidde: Kral Abdulaziz Üniversitesi Yay. Tsz.), 3; Ahmed Muhammed Mahmud Nassâr, Mebâdiu iktisadi'l-Islamî (Beyrut: Dâru'n-Nefâis, 2010), 93-105.

2 Tabakoğlu, İslami İlimlerde Usul/Metodoloji Meselesi II, 1161; Karadâğ̂̀, el-Medhal ila iktisadi'l-İslamî, 1: 205; Refik Yunus Misrî, Usûlu İktisâdi'l-İslâmî, (Beyrut, Daru'şŞamiyye, 2012), 30.

3 Asad Zaman, "An Islamic Approach to Inequality and Poverty" JKAU: Islamic Econ, 31/1, (January, 2018): 78. 
İslam iktisat düşüncesinin yoksulluğa yaklaşımını ortaya koymak üzere öncelikle fakirlik/yoksulluk olgusunu tanım, sebep ve sonuçları bakımından inceleyeceğiz. Bilahare İslam iktisat düşüncesinin bu probleme karşı aldığ1 önlemleri ana hatlarıyla açıklayarak bir sonuca ulaşmaya çalışacağız. Araştırmada İslam iktisat düşüncesini merkeze alarak bu düşüncenin itikadi, hukuki, tasavvufi ve sosyolojik boyutlarından yararlanacağız.

\section{Yoksulluk ve Fakirlik Kavramları}

Türkçede yoksulluk "bir şeye onsuz yapamayacak derecede bağlı olmak ve yokluk" şeklinde tanımlanırken ${ }^{4}$ fakirlik ile aynı anlamda kullanılmaktadır. Fakirlik kavramı ise sözlükte fakr mastarından türemiş olup "delmek, kırmak, kazmak veya bükmek" anlamlarına gelmektedir. Bu mastardan türeyen "fâkırra" kelimesi beli büken büyük bela ve musibet anlamındadır. Fakr mastarından türeyen fakîr kelimesi sözlükte omurgası kırılan ve bu sebeple işlerini tek başına yapmaya güç yetiremeyen kimse anlamındadır. Sözlük anlamıyla bağlantılı olmak üzere, maddi sıkıntıdan dolayı ihtiyaçlarını karşılamaya gücü yetmeyen ve bu konuda başkasına muhtaç olan kimselere fakîr ismi verilmiştir. ${ }^{5}$

İslam iktisat düşüncesinde yoksulluk derecelerini ifade etmek üzere fakir ve miskin olmak üzere iki temel kavram kullanılmıştır. Bu iki kavram örf açısından genellikle aynı anlamda kullanılsa da iktisadi bir terim olarak farklı anlamları ifade etmektedir. ${ }^{6}$ Hanefi fakihlere göre fakir nisap miktarı altında mala sahip olan; miskin ise hiçbir şeye sahip olmayan kimsedir. ${ }^{7}$ Buna göre miskin, fakirden daha alt bir ekonomik dereceyi ifade etmektedir. Malikî, Şafîi ve Hanbelî fakihlerin terminolojisinde fakir, kendisinin ve bakmakla yükümlü olduğu

4 Şemsettin Sami, Kamûs-ı Türkî̀, (İstanbul, Çağrı Yayınları, 1996), 76.

5 Ebu'l-Kasım Mahmûd b. Ömer b. Muhammed ez-Zemahşerî, Esâsu'l-Belâğa, (Beyrut: Dâru İhyai't-Turâsi'l-'Arabî, 2001), s.572; Cemâlüddîn Muhammed b. Mükerrem b. Alî b. Ahmed İbn Manzur, Lisânu'l'Arab, (Kahire: Daru'l-Me'arife, tsz.), 5: 3444; Osman Eskicioğlu, "Fakr", TDV İlam Ansiklopedisi (Ankara: TDV Yay., 1995), 12: 129.

6 Muvaffakuddin Abdullah b. Ahmed İbn Kudâme, eş-Şerbu'l-kebîr, (Beyrut: Dâru'lF1kr 2011), 2: 285.

7 Kemâluddîn Muhammed b. Abdulvahid İbn Hümam, Fethu'l-kadîr, (Beyrut: Dâru'lKutubi'l-'İlmiyye, 2003), 2: 265-266. 
kimselerin zorunlu ihtiyaçlarını karşılayacak bir mala ve çalışma imkânına sahip olmayan kimsedir. Miskin ise kişinin malı bulunmasına ve çalışmasina rağmen kendisinin, bakmakla yükümlü olduğu kimselerin zorunlu ihtiyaçlarını karşılayamayan kimseyi ifade etmektedir. Ekonomik açıdan fakirlik miskinlikten bir alt dereceye tekabül etmektedir. ${ }^{8}$ Buna karşılık İmam Ebu Yusufa ve Malikîler'den İbn Kasım'a göre fakirlik ile miskinlik aynı anlama gelmektedir.' Ancak bu iki kavram zekâtın verileceği sınıfları belirleyen ayette birbirine atfedilmiştir. Matuf ile matuf aleyh arasındaki farktan hareketle bu iki kavramın ekonomik açıdan farklı dereceleri ifade ettiğini belirtmek gerekir.

İbn Hazm maddi durumu fakirlik, miskinlik, kifâyet ve zenginlik olmak üzere dört kısma ayırmaktadır. Ona göre fakirlik hiçbir şeye sahip olmamak, miskinlik nisap miktarının altında bir mala sahip olmaktır. Kifayet nisap miktarı bir malla birlikte kimseye muhtaç olmamak, zenginlik ise nisabın üzerinde mal varlığına sahip olmaktır. Zenginler ve kifayet sahipleri fakir ve miskinlerin ihtiyaçlarını gidermekle mükelleftir. ${ }^{10}$ Klasik fikıh terminolojisinde fakir ile miskin kavramlarıla ilgili arz edilen ihtilaflar, yoksulluk sınırı konusunda bir derecelendirmeye gidildiğini göstermektedir. Öte yandan bu iki kavram fikıh literatüründe şefkat, merhamet, yardımlaşma ve dayanışma anlamlarıyla iç içedir.

İktisat biliminde yoksulluk "insanlarn yasamlarm devam ettirebilmesi için temel ibtiyaçlarm kearşlamada açe düsme durumu" olarak tanımlanmıștır. ${ }^{11}$ $\mathrm{Bu}$ tanım yukarıdaki fikhi tanımlara yakın olmakla birlikte, yoksulluğun ara derecelerini ifade etmemektedir. İktisat biliminde yoksulluğun derecelerini ifade etmek üzere ana hatlarıla mutlak yoksulluk ve göreli yoksulluk şeklinde ikili bir ayrıma gidilmiştir. Bunun yanında yoksulluk sınırını belirlemede esas alınan parametlere göre oldukça farklı derecelendirmeler yapılmış ve her bir derece için farklı bir kavram

\footnotetext{
8 İbn Kudame, eş-Şerbu'l-kebîr, 2: 688-689.

9 İbn Kudame, ess-Serbu'l-kebîr, 2: 688; Yusuf Karadâvî, Fikhu'z-žekât, (Beyrut: Müessesetu'r-Risâle, 2011), 368.

10 Ebu Muhammed Ali b. Ahmed b. Said İbn Hazm, el-Muhalla, (Beyrut: Dâru'lKutubi'l-'̇̉miyye, 2010), 4: 272.

11 Yunus Taş- Selami Özcan “Türkiye'de ve Dünya'da Yoksulluk Üzerine Bir Araştırma", International Conference On Eurasian Economies, (2012): 423.
} 
kullanılmıştır. ${ }^{12}$ Mutlak yoksulluk bireyin hayatını sürdürmek için yalnızca temel ihtiyaçlarını karşılayacak durumda olması, yardım edilmediği takdirde ölüm tehlikesine maruz kalma durumu olarak açıklanmıştır. Göreli yoksulluk bireyin yardım almaksızın temel ihtiyaçlarını karşılaması ancak sağlık, eğitim ve kültür gibi parametler esas alındığında ekonomik ortalamanın altında kalmasıdır. ${ }^{13}$

Klasik fikıhtaki fakirlik, miskinlik ve kifayet derecelendirmesi günümüz iktisat bilimindeki yoksulluk derecelendirmelerine benzerlik göstermektedir. Hanefî fikıh doktrininde fakirliğin nisapla birlikte borç ve asli ihtiyaç parametlerine göre belirlenmesi arz edilen iktisattaki yoksulluk derecelendirmesine yakındır. Fakirlik sinırlarını belirleyen parametreler fikıh mezhepleri arasında da değişkenlik gösterebilmektedir. Buna ek olarak sosyo-ekonomik şartlar muvacehesinde mezhep içtihatlarının kendi dönemlerindeki belirledikleri yoksulluk sinırları ile günümüz sanayi toplumundaki yoksulluk sınırlarının örtüşüp örtüşmediği tartışmalıdır. Zira yoksulluk dereceleri zamansal açıdan tarım toplumundan sanayi toplumuna, aynı şekilde bir bölgeden diğerine değişkenlik gösterebilmektedir. Sanayi toplumundaki ihtiyaçlar tarım toplumundaki ihtiyaçlardan farklıdır. Bir bölgede zengin sayılanların, ekonomik şartlara bağlı olarak bir başka bölgeye nispetle fakir sayılması mümkündür.

\section{2. İslam İktisadında Yoksulluk Sınırları}

İktisat biliminde yoksulluk sınırını tespit etmek üzere ortalama insan ömrü, eğitim seviyesi, sağlık ve kişi başına düşen gayrı safi milli gelir gibi parametler esas alınmaktadır. ${ }^{14}$ Klasik fikıh literatüründe ise yoksulluk sınırını tespit etmek üzere nisap ölçütü esas alınmaktadır. Nisabın belirlenmesinde nisabı kuşatan borç ve asli ihtiyaç faktörlerinin dikkate alınıp alınmayacağı ise doktrinde tartışmalıdır.

Hanefî hukukçular fakirlik sınırını belirlemede nisap ölçüsünü esas alırken; malın nisaba ulaşıp ulaşmadığını tespit etmek için de asli

12 Emin, Dünya Yoksulluk ve Eşitsizllik Raporu, 2; Taş-Özcan, “Türkiye'de ve Dünya'da Yoksulluk Üzerine Bir Araştırma”, 424.

13 Emin, Dünya Yoksulluk ve Eşitsizllik Raporu, 2; Mahmut Bozan, "Yoksulluk Algisına Farklı Bir Bakış”, Bartın Üniversitesi İ̈BF Dergisi, 8/15, (2017): 394

14 Emrah Ayaşlıoğlu, Yoksulluk ve Reklam Algzsı, (Yüksek Lisans Tezi, Ankara Üniversitesi, 2007), 17-18. 
ihtiyaç ve borç parametlerini dikkate almışlardır. Buna bağlı olarak nisabı üç kısımda değerlendirmişlerdir: Birincisi; asli ihtiyaç ve borç düşüldükten sonra nisap miktarı zekât malına sahip olanlar zengin, nisap miktarından az mala sahip olanlar fakirdir. İkincisi; asli ihtiyaçların ve borcun dışında zekâta tabi malların dışında kıymet bakımından nisap miktarını aşan bir mala yani nisabı istiğnaya sahip olmaktır. Bu durumda zekât vermek vacip olmadığ1 gibi, zekât almak da caiz değildir. Üçüncüsü; günlük asgari geçim için temel gıdalara sahip olmak, çalışıp kazanabilecek durumda olma veya elli dirheme sahip olma durumudur. Böyle bir durumda dilenmek ve mali yardım talebinde bulunmak caiz görülmezken zekât almada bir sakınca görülmemiştir. ${ }^{15}$ Buna göre Hanefî hukukçular fakirlik sınırını belirlemede nisabı kuşatan nisabı kuşatan ekonomik koşulları dikkate alarak bunu asli ihtiyaç ve borçla sınırlandırmaktadır.

İmam Malik nisabın belirlenmesinde borç ve asli ihtiyaçları dikkate almaya ek olarak, asli ihtiyaçların içtihadî olduğu; bu ihtiyaçların zamana, mekâna ve şartlara göre değişkenlik gösterebileceği görüşündedir. ${ }^{16}$ Şafî̀ ve Hanbelî hukukçulara göre fakirlik sınırı kifâyet olarak belirlenmiştir. Kendisinin ve ailesinin asli ihtiyaçlarını karşılamak üzere yeterli düzeyde mal sahibi olan, çalışarak kazanabilen kimseler fakir değildir. Kifayet sahibi olmayanlar ise fakirdir. ${ }^{17}$

Malikî ve Hanefi fakihlerin nisap konusunda asli ihtiyaç ve borç faktörünü dikkate almaktadır. Malikî fakihler asli ihtiyacın içtihadî olduğunu belirtmekle onun kapsamını esnek tutmaktadır. Şafîi ve Hanbelî fakihler fakirlik sınırını belirlemede kifayeti esas almaktadır. Hanbelî fakihler nisabın belirlenmesinde borç faktörünü dikkate alırken, Şafiî fakihler borcu dikkate almamaktadır. Bu bakımdan yoksulluk sınırını

15 İbn Hümam, Fethu'l-kadîr, 2: 266; Muhammed Emin İbn Abidin, Reddu'l-mubtâr 'ale'd-durrri'l-mubtâr, (Beyrut: Daru'l-F1kr, 2000), 2: 86-88; Ebubekir b. Mes'ud b. Ahmed el-Kâsânî, el-Bedaiu's-sanaî fì tertîbi's-şerayi', (Beyrut: Daru İhyai't-Turâsi'l'Arabî, 1998), 2: 48.

16 Muhammed b. Ahmed b. Muhammed b. Ahmed İbn Rüşd, Bidâyetu'l-müctehid, (Beyrut: Daru'l-Kutubi'l-'Ilmiyye, 2007), 254.

17 Ebu Zekeriyya Muhyiddin Yahya b. Şeref en-Nevevî, el-Mecmû́ (Beyrut: Daru İhyai't-Turasi'l-'Arabî, tsz), 4: 190. 
en esnek tutan görüş Malikîlere aittir. Bunu sırayla Hanefî, Hanbelî ve Şafî̀ fakihler takip etmektedir.

Günümüzde İmam Malik'in görüşünü esas alanlar, asli ihtiyaçların zamana, mekâna ve şartlara göre yeniden takdir edilmesi gerektiğini savunmuşlardır. ${ }^{18}$ Buna bağlı olarak asli ihtiyaçları bir diğer ifadeyle insani yoksulluk sınırını tespit etmede eğitim, sağlık, kültür ve gayrı safi milli gelir ölçütlerinin esas alınabileceğini, İslam iktisadının bu ölçütleri asli ihtiyaç ve borç kavramlarıyla ifade ettiğini belirtmişlerdir. ${ }^{19}$ Bunun yanında sağlık ve eğitim giderlerini, bir yıllık geçim imkânını ve araç sahibi olmayı asli ihtiyaç kapsamına alanlar da bulunmaktadır. ${ }^{20}$

Yoksulluk sınırını belirlemende "ev, ev eşyası, bir yıllık nafaka, sağlik, eğitim giderleri ve normal bir araç" temel ihtiyaçlardan kabul edilebilir. Ancak İslam iktisadı açısından havaic-i asliyeyi tespit etmek üzere günümüz parametlerini olduğu gibi esas almanın isabetli olup olmayacağı tartışmalıdır. ${ }^{21}$ Zira günümüzde zorunlu olmayan ihtiyaçların görenek, alıskanlık veya reklam yoluyla zorunlu hale getirildiği görülmektedir. Asli ihtiyaç kapsamını zorunlu olmayan ihtiyaçlarla genişletmek, gelirin giderleri karşılayamaz hale gelmesine yol açabilmektedir. Buna bağlı olarak faiz türünden haram yollara sevk edebilmekte; genel anlamda infaktan özelde ise zekâttan kaçınmaya yol açabilmektedir. Yoksulluk sınırını belirlemede Malikî içtihat ihtiyaç çerçevesini genişletmeye müsaittir. Şafîi içtihat bu çerçeveyi daraltırken, Hanefî içtihat ise orta yolu bulmaktadır. Günümüzde yoksulluk sınırını

18 Hayrettin Karaman, İslam Ticaret İlmihali, (İstanbul: İz Yayıncılık, 2012), 377; Karadavi, Fıkbu'z-zek'ât, 115.

19 Karadaği, el-Medhal ila İktisadi'l-İslamî, 1: 234.

20 Yusuf Balta, "Belli Başlı Kaynaklarda Havaic-i Asliyye Listeleri”. Bülent Ecevit Üniversitesi ilahiyat Fakültesi Dergisi, 3/1, (2016): 235.

212018 yılı verilerinde yoksulluk sınırı 6.355 tl olarak belirlenmiştir. Bu konuda esas alınan parametrelerin İslam iktisadının zorunlu ihtiyaç kabul ettiği veya zorunlu kabul etmediği tartışmalı bir husus olmakla birlikte ayrı bir çalışmanın konusudur. Ancak şunu belirtmekte fayda vardır: Bu tür parametlerin gerçeği ve zorunlu ihtiyaç sınırını ne derece doğru ortaya koyduğunu tekrar gözden geçirmek gerekmektedir. Zira bu tür istatiski sonuçlar şartlar muvacehesinde bir bölgeden diğerine farklılaşabilmektedir. Dolayısıyla her toplumun ortalama asli ihtiyaç sınırını belirleme konusunda o toplumun şartlarının dikkate almanın daha isabetli olduğunu düşünmekteyiz. (Bkz. http://tuik.gov.tr/Start.do, Erişim: 31.01.2019) 
belirlemede Hanefi görüş esas alınabilir. Buna göre zorunlu asli ihtiyaçların ve borcun dışında nisaba sahip olanların zekatla mükellef oldukları söylenebilir. Çünkü günümüzde zorunlu olmayan ihtiyaçlar zorunlu hale getirilmiştir. İhtiyaç kapsamı konusunda açık uçlu "içtihadî ihtiyaçlar" kavramının yerine "zorunlu ihtiyaçlar" kavramını esas almak israf mahiyetindeki lüks ihtiyaçları dışarıda bırakarak mükellefi infakta bulunmaya teşvik edecektir. İslam iktisadının temel gayelerinden biri de infak vasitasılyla yoksulluğu gidermektir.

\section{Yoksulluğun Başlıca Sebepleri ve Sonuçları}

Küresel çapta yoksullukla ilgili her yll çeşitli araştırmalar yapılmaktadır. Bu konudaki bazı araştırma verileri şöyledir: 2018 Ekim İHH yoksulluk araştırma raporuna göre dünyadaki en zengin 42 kişinin mal varlığ1 3,6 milyar insanın, yani dünya nüfusunun \%50'sinin mal varlığına tekabül etmektedir. En zengin 10 ülkenin geliri, en fakir 10 ülkenin gelirinden 77 kat fazladır. 22019 UNICEF raporuna göre: Yemen'de 400.000'den fazla çocuğa yetersiz beslenme teşhisi konulmuştur. 7 milyon çocuk her gece yatağa aç gitmektedir. 2 milyondan fazla çocuk okula gidememektedir. 5 yaşın altında olan 66.000 çocuk önlenebilir hastalıklardan dolayı vefat etmiştir. ${ }^{23}$

Yukarıdaki veriler yoksulluğun küresel çapta boyutlarını ortaya koymakta, onun küreselleşen dünyanın ortak bir problemi olduğunu göstermektedir. Kapitalizmin küreselleşmesiyle birlikte dünya sermayesinin aslan payı her toplum içinde elit bir kesimde toplanmıştır. Dünya çapında belirli ülkelerde ve bu ülkeler içinde azınlık bir elitin elinde toplanmıştır. İslam iktisat düşüncesi ise dini, hukuki, ahlaki ve insani boyutlarıyla paylaşımı esas alarak böyle bir kutuplaşmaya engel olmayı hedeflemektedir.

\subsection{Yoksulluğun Başlica Sebepleri}

Yoksulluk sosyolojik açıdan tek sebeple aç1klanamayacak bir olgudur. Dünya genelinde yoksulluk bireysel, toplumsal, iktisadi ve siyasi düzlemdeki sebeplerin yanı sıra dini, ahlaki ve insani bir ödev olarak

22 Emin, Dünya Yoksulluk ve Esitsizlik Raporu, 1.

23 https://www.unicefturk.org/yazi/GeertCappelaere, Erişim: 31.01.2019. 
paylaşımın terk edilmesinden kaynaklanmaktadır. Bu sebepler bir toplumdan diğerine farklılaşmaktadır.

İbn Hazm, zenginlerin fakirlerin ihtiyacını karşılamakla yükümlü olduğunu ifade ettikten sonra, fakirliğin sebebini zenginlere bağlamıştır. Bira toplumda fakir varsa orada görevini yapmayan bir zengin vardır düşüncesiyle, zenginlerin fakirlerden dolayı azaba çarptırılacaklarını belirtmiştir. ${ }^{24}$ Ancak paylaşım konusunda üzerine düşen mükellefiyeti yerine getiren zenginlerin, söz konusu çerçeveye dahil olmadıkları açıktır. Yoksulluğun önemli sebeplerinden biri zenginlerin paylaşımı terk etmesi olsa bile, yoksulluk yalnızca zenginlere indirgemek suretiyle açıklanamaz. Yoksulluğun sebebini sadece kapitalizme, zenginlere, iktisadi düzendeki bozukluklara veya sosyal adaletin yokluğuna indirgeyerek bireyin ihmalini görmezden gelmek isabetli değildir. ${ }^{25}$ Aynı şekilde yoksulluğu yalnızca bireyin kendisine indirgeyerek, yoksulluğun sebeplerinden kapitalizm, sosyo-ekonomik siyasi şartlar, zenginlerin paylaşımı terk etmesi ve sosyal adaletsizlik faktörü göz ardı edilemez. Çünkü yoksulluk birey, toplum ve devletler bazında birçok sebepten kaynaklanmaktadır. Bu sebepleri ana hatlarıyla bireysel sebepler, iç sebepler ve diş sebepler şeklinde sinıflandırmak mümkündür: ${ }^{26}$

Bireysel sebepler: Benmerkezcilik, cimrilik, israf, paylaşmama ve fakirleşme korkusu; öte yandan tembellik, üretimin terk edilmesi, tüketim çllg1nlı̆̆1, israf, kumar, faiz ve hazırcllık türünden zihniyetler yoksulluğun bireysel sebeplerindendir.

İç Sebepler: İç savaşlar, darbeler, siyasi istikrarsılılklar, doğal afetler, ekonomik krizler, faiz, enflasyon, ekonomik tekelleşme, eğitimaraştırma faaliyetlerinin zayıflaması, ticaret-ziraat ve sanayileşme bazında üretimin ihmal edilmesi, teknolojik açıdan geri kalmışlık ve paylaşımın terk edilmesi yoksulluğun sosyolojik iç sebepleri arasındadır.

Dış Sebepler: Dış sebepler kapsamında ekonomik yaptırımlar, ambargolar, yer altı kaynaklarının sömürülmesi ve faiz gibi sebepler

24 Ebu Muhammed Ali b. Ahmed b. Said İbn Hazm, el-Muhalla, (Beyrut: Dâru’lKutubi'l-'̇̉miyye, 2010), 4: 281-283.

25 Usame Sadık Tayyib v.dğr., Mukâfehatu'l-fakr, (Cidde, Merkezu'l-İntâci’l-İlâmî, 2006), 70; Yılmaz Daşl1, "Yoksullukla Mücadelede Yeni Bir Yaklaşım: İşlevsel Yoksulluk" Turkish Studies, 13/26, (2018): 464.

26 Usame Sadık Tayyib v.dğr., Mukâfehatu'l-faker, 70; Karadaği, el-Medhal ila İktisadi'lİslamî, 1: 265-266. 
zikredilebilir. ${ }^{27}$ Şüphesiz bu sebepler bir toplumdan diğerine değişkenlik gösterebilmektedir. Zikredilenlerin dişında yoksulluğun farklı sebepleri de bulunabilir. Her yoksulluğun kendisine göre sebepleri farklılaşabilmektedir.

Bu kapsamda yoksulluğa yol açıp açmadığ tartışmalı olan bazı sebepler de bulunmaktadır. Örneğin tasavvufun ₹ühbd ve faker düşüncesini esas alarak fakirliğe/yoksulluğa teşvik ettiği, toplumu yoksulluğa sürüklediği ve tasavvufun fakirlik zihniyetinin cümlesinden olduğu iddia edilmiştir. ${ }^{28}$ Ancak tasavvuf düşüncesindeki zühbd mülkiyeti helalinden kazanmak, paylaşım yoluyla gerekli yerlere harcamak şeklinde tanımlanmış; dünyayı kesben değil kalben terk etmek, masiyetten uzak durmak ve insanların elindekine göz dikmemek şeklinde açıklanmıştır. ${ }^{29}$ $\mathrm{Bu}$ açıdan kural olarak zühdün maddi yoksullukla bir ilişkisi bulunmamaktadır. Tasavvufta fakr ile maddi fakirlik değil, kişinin Allah'a karşı manen fakirliğini idrak etmesi kastedilmiştir. Övgüye layık olan fakr "bir şeye sahibi olmamak" değil "sahip olunan şeylere köle olmamak" şeklinde açılanmıştır. ${ }^{30} \mathrm{Bu}$ yönüyle sahih bir tasavvuf düşüncesinin bireyi, toplumu veya devleti maddi anlamda fakirliğe teşvik etmekten uzak olduğu anlaşılmaktadır. Öte yandan tasavvuf kendisini ihsan temeline dayalı sevgi, kardeşlik, sosyal dayanışma, yardımlaşma ve paylaşım kurumu olarak arz etmektedir. Tasavvuftaki fütüvvet anlayıș1 tarihi süreçte Anadolu'da ahilik teşkilatı olarak kurumsallaşmış; ahlaki, manevi ve hukuki açlardan İslam ekonomisini olumlu yönde etkilemiştir. $^{31}$

27 Münir Tireli, Küreselleşme ve Yoksulluk: Birleșişs Milletle ve Dünya Bankası Göstergeleri Isı̆ğnda Bir Analiz, (Uzmanlık Tezi, Ankara, 2009), 31; Emin, Dünya Yoksulluk ve Eşitsiz̨lik Raporu, 2018: 5.

28 Yusuf Karadavi, Muskiletu'l-faker ve keyfe 'alecehe'l-Islam, (Beyrut: Müessesetu'r-Risâle, 1985), 7.

29 Yaşar Nuri Öztürk, Kur'an ve Sünnete Göre Tasavvuf, (İstanbul, Yeni Boyut Yay., 1998), 185-186.

30 Süleyman Uludăg, Kuseyrî Risalesi, (İstanbul: Dergâh Yay., 1999), 208, 363; Kamil Y1lmaz, Tasavvuf ve Tarikatlar, (İstanbul, Ensar Yay., 2007), 200, 202; Yaşar Nuri Öztürk, Kur'an ve Sünnete Göre Tasavvuf, 178-195.

31 Nevzat Aydın, "Ahîlikte İș ve Ticaret Ahlakının Hz. Peygamber’in Sünnetindeki Temel Referansları”, Bülent Ecevit Üniversitesi İlahiyat Fakültesi Dergisi, 2/1, (2015), 
Yoksulluk olgusu bir hukuk problemi olmadan önce bir zihniyet problemidir. Bu sebeple yanlış yorumlanması halinde yalnızca tasavvuf düşüncesinin değil, genel anlamda her türlü dini düşüncenin maddeten yoksulluğa zemin hazırlaması mümkündür. Nitekim cebriye düşüncesinde fakirlik geleceğe dönük bir alın yazısı olarak görülmüştür. ${ }^{32}$ Oysa yoksulluğa/fakirliğe karşı kitap, sünnet ve içtihat kapsamında alınan tedbirler bu düşüncenin isabetsiz olduğunu göstermektedir. (Bkz. Necm, 53/59). Buna göre genelde dini düşüncenin özelde tasavvufi düşüncenin aslı fakirliğe yol açmamakta, çalışmaya teşvik ederken paylaşımı öngörmektedir. Ancak bu durum dini/tasavvufi düşüncenin aslı için geçerlidir. Batıl dini anlayışlar için aynı şey söylenemez. Nitekim dinin yanlış yorumlanması halinde, dini anlayış dinin aslından farklılaşmaktadır.

Michel Chossudovsky, yoksulluk problemini teknolojinin gelişmesiyle birlikte makineleşmeye bağlamıştır. Luddist kuram doğrudan veya dolaylı olarak teknoloji karşıtlı̆̆ üzerine kurulmuştur. Bu kuram, makineleşmeyle birlikte işsizlik sorununun arttığını ileri sürmektedir. İssizliğe ek olarak enflasyonun da artması alım gücünü zayıflatarak fakirliğe yol açmaktadır. ${ }^{33}$ Ancak bunun aksine makineleşmeyle birlikte istihdam alanlarının oluştuğu, işsizliğin zayıfladığı; teknolojik açıdan ileri olan toplumların fakir olmadıkları, işsizlik oranlarının düşük olduğu ve ekonomik açıdan güçlü oldukları da bir gerçektir. ${ }^{34} \mathrm{Bu}$ nedenle genel anlamda işsizlik ve enflasyonun fakirliğe yol açması mümkün olmakla birlikte işsizliği bu kapsamda yoksulluğu yalnızca makineleşme sebebine bağlamak isabetli görünmemektedir.

\subsection{Yoksulluğun Başlica Sonuçları}

İslam'ın değerler sisteminde fakirlik hakir görülme, zenginlik ise üstünlük sebebi değildir. ${ }^{35}$ Bunun aksine her iki durum zengin ve fakirin sınandığı bir süreçtir. Fakirler yokluk karşısında sabırla, zenginler ise

$$
\text { 87-104. }
$$

32 Karadavi, Muskiletu'l-faker, 8.

33 Michel Chossudovsky, 'Avlemetu'l-fakr , (Misir: Mektebetu İnsaniyyat 2012), 309310.

34 Bkz. Serdar Orhan, Fatih Savuk, "Emek Teknoloji İşsizlik İlişkisi”, CSGB Calı̧sma Dünyası Dergisi, 2/2, (Ağustos, 2014): 12, 22.

35 Mustafa Macit, "Yoksulluk İnsan Onuru ve Din", Atatürk Üniversitesi Ilabiyat Fakültesi Dergisi, 41/1, (2014): 102. 
varlık karşısında şükür ve paylaşımla sınanmaktadır. İslam iktisat düşüncesi yoksulluk karşısında insan onurunu esas alarak korumaktadır. ${ }^{36}$ Yoksulluğun birey, toplum ve devlet bazındaki muhtemel olumsuz sonuçlarını önlenmeyi hedeflemektedir. Yoksulluğun zemin hazırladığı olumsuz sonuçların genel geçer olmadığını, kişiden kişiye değiştiğini, bir toplumdan diğerine göre farklılaştığını belirtmekte yarar vardır. Öte yandan inancın, sabrın, paylaşımın, ahlaki ve insani değerlerin güçlü olduğu toplumlarda fakirliğin olumsuz sonuçlara yol açması zordur.

Fakirliğin olumsuz sonuçlarını ele alırken, yoksulların onurunu rencide edecek türden bozuk algıların, yoksulluğun bizzat kendisinden daha vahim bir sorun olduğunu belirtmek gerekir. ${ }^{37}$ Dolayisiyla yoksulluk/fakirlik olgusu, bunun sebepleri ve muhtemel sonuçları insan onurunu koruma bağlamında mülahaza edilmelidir. Mantıksal açıdan "yoksulluk" ile "olumsuzluk" arasında zorunlu bir neden sonuç ilişkisi bulunmamaktadır. Bununla birlikte İslam iktisadının temel kaynaklarından hareketle psiko-sosyal ve kültürel açıdan yoksulluğun sebep olabileceği muhtemel sonuçları tespit etmek, bu probleme karş1 farkındalık uyandırarak önlem alma bakımından önem arz etmektedir. Yoksulluk sadece olumsuz sonuçlara indirgenemez, onun muhtemel olduğu olumlu/olumsuz sonuçlar şöyle açıklanabilir:

\section{Olumlu Firsatlar1:}

Yoksulluk yalnızca olumsuzluğa indirgenemez. Bu olgunun öncelikle olduğu gibi kabul edilmesi, gerekli önlemleri alarak işlevsel hale getirmek gerekir. Yoksulluk Allah'a yakınlaşma, iyilik, paylaşım ve merhamet duygusunun güçlenmesi için bir firsat olabilmektedir. Sabır yoluyla manen olgunlaşma sürecine katkıda bulunabilir. Azim, çaba ve

36 Bkz. "Andolsun sizleri siz̨i biraz, korku, biraz açlkela mallardan, canlardan ve ürünlerden biraz eksiltmekle sinari, sabredenleri müjdele." (Bakara, 2/155); "Ey iman edenler! Sadakalarmı̨ başa kakmak ve gönül kırmak suretiyle boșa çıkarmayn." Bakara, 2/264; "(Sadakalar) Allah yolunda adanmıs, (bu yüzden) yeryüzünde (maişeti için) dolaşamayan fakirler içindir. Iffetli olmalarndan dolayn, ballerini bilmeyen kimse onlar zengin zanneder. Onlar simalarndan tanirsin. Israr ederek insanlardan bir şey istemezler. O balde bayurdan ne harcarsanı, süphesiz. Allah, onu hakkeryla bilendir.” (Bakara, 2/173).

37 Bkz. Açıkgöz-Yusufoğlu, “Türkiye'de Yoksulluk Olgusu ve Toplumsal Yansimaları", 99. 
gayret neticesinde nimete kavuşmaya vesile olabilir. Yoksulluğu anlayarak fakirlere el uzatma konusunda yaşanan bir tecrübeye dönüştürülebilir. Her zorluktan sonra bir kolayllğın bulunduğu izahtan varestedir. Öte yandan toplumsal refah seviyesindeki mutlak eşitlik eşyanın tabiatına ve sosyolojik gerçekliğe aykırıdır. Zenginliğe karşı fakirlik olgusu sevgi, paylaşım, yardımlaşma, îsar, çalışma ve istihdam türünden insani değerlerin sürdürülmesini sağlamaktadır. Bu yönüyle fakirlik psiko-sosyal ve iktisadi açıdan işlevsellik kazanmaktadır. Zira refah seviyesindeki mutlak eşitlik toplumsal açıdan ihtiyaç duyulan faaliyetleri durma noktasına getirebilir. Allah Teâla hikmetinin gereği olarak insanlığ1 sınamak, bir kısmının diğerini çalıştırması ve dünyanın imar edilmesini sağlamak için kabiliyet farkına bağlı olarak farklı iktisadi dereceler takdir etmiştir. ${ }^{38}$ İktisadi açıdan mutlak eşitlik iddiası özel mülkiyetin inkar edilmesini, emek ve sermayede ortaklığ1 gerektirir. Oysa özel mülkiyet duygusu fitratta var olduğundan, fitratın gereğini inkâr eden bir iktisadi bir anlayış sürdürülemez. Öte yandan toplumu meydana getiren fertlerin kabiliyetleri, bireysel farkl11ıkları sözgelimi engellilik, hastalık durumları emek konusunda mutlak eşitliği, buna bağlı olarak sermeye konusundaki mutlak eşitliği imkânsız hale getirmektedir.

\section{2. İnanç ve ahlak bazındaki muhtemel olumsuz sonuçları:}

Yoksulluk inanç bazında isyana, sosyalist akımların güçlenmesine ve kazanç bakımından haksız kazanç yollarına zemin hazırlayabilir. ${ }^{39}$ Ayette: "Fakirlik korkusundan çocuklarmı öldürmeyin" (İsra, 17/31) buyrulmuştur. $\mathrm{Bu}$ ayet inanç, sabır, tevekkül ve infak yoluyla önlem alınmayan yoksulluğun sebep olabileceği sonuçları ifade etmektedir. ${ }^{40} \mathrm{~Hz}$. Peygamber "Allab'm küfürden ve fakirlikten sana sığmmm." fakirliğe karşı inanç, sabır, infak gibi önlemler alınmadığ1 takdirde bu musibetin isyan ve inkarla sonuçlanması ihtimal dahilindedir. Allah Teâlâ fakirlere zenginlerin malından bir pay ayırmıştır. Bu hakkın verilmemesi yalnızlık, dışlanmışık hissi, yaratıcıya ve topluma karşı güvenin

\footnotetext{
38 Bkz. "Dünya hayatında onlarn geşimliklerini biæ, paylaş̧ırdı. Bir kısm diğerini istihdam etsin dive kimini kiminden derecelerle üstün keldık." (Zuhruf, 43/32).

39 Karadağ̂̀, el-Medhal ila İktisadi'l-Islamî, 1: 252.

40 Muhammed b. Cerîr et-Taberî, Camiu'l-Beyân fî̀ Te'vîli'l-Kur'ân, (Beyrut, Müessesetu'r-Risâle, 2000), 17: 436.

41 Tirmizi, Daâvat, 121.
} 
zayıflamas1 türünden olumsuzluklara sebep olabilir. Hz. Peygamber "Allab'm günabtan ve borçtan sana sı̆̆mmm" şeklinde dua etmiştir. Bunun sebebini soran sahabiye "kişi borclandiğnda yalan söyler ve verdiği sözde durmaz:" olumsuz sonuçlardan Allah'a sığınmaktadır. Bir taraftan önlem alınmadığ takdirde yoksulluğun sebep olabileceği problemlere dikkat çekmekte; diğer taraftan yoksulluğa karşı maddi ve manevi tedbirleri alarak inanci, sevgiyi ve insan onurunu korumanın gerekliliğini vurgulamaktadır.

Fakirlik kadar zenginliğin de ahlaki bozulma ve isyanla sonuçlanması mümkündür. Allah Teâla "Hayır, andolsun ki insan kendini müstağni (ibtiyacsıฆ, yeterli) görünce haddi aşar" buyurmuştur. (Alak, 96/6-7). Gerekli önlemlerin alınmaması halinde zenginliğin itrafa/şımarıklığa dönüşmesi, yüce insani değerlerin dejenere olmasina yol açabilir. $\mathrm{Bu}$ kapsamda zenginlik şecaat, beceri, iyilik/hayırseverlik duygularını zayıflatarak daha fazla kazanmak için hile, sahtekarlık, bencillik duygularını besleyebilir. ${ }^{43}$ İslam iktisat düşüncesi bireysel bazda zenginliğin inanç, ahlak, şükür ve infak değerleriyle bütünleşmesini hedeflemektedir. Allah Teala "şükerederseniz, and olsun ki, siz̨e karşıliğm arturrm; nankörlük ederseniz bilin ki azabım pek cetindir" buyurmuştur. (İbrahim, 14/7). İslam iktisat düşüncesi zenginliği, dinin belirlediği paylaşım yollarıyla tüm insanlık için faydalı bir araca dönüştürmektedir. $\mathrm{Bu}$ açıdan zenginlik mutlak bir mülkiyet değil toplumun ve dinin yararına kullanılması gereken bir imkândır. ${ }^{44}$

İslam İktisat düşüncesi ahlaki/manevi açıdan "sabır" ve "şükür" sabitelerine dayanmaktadır. Yoksulluğa karşı sabır musibeti hafifletmektedir. Onu firsata dönüştürerek çalışma azmini güçlendirmektedir. Allah'a yakınlaşmaya, mutluluğa ve ebedi bir zenginliği kazanmaya vesile olabilmektedir. İsyan ise maddi musibete manevi bir musibet ekleyerek onu iki katına çıkarmaktadır. Zenginliğe

42 Buhari, Salât, 56.

43 Veliyuddin Abdurrahman b. Muhammed İbn Haldûn, el-Mukaddime, (Dımaşk, Daru Ya'rûb, 2004), 84.

44 Anwar Fakhri Omar, "Bartulmal's Potent1al as Trustee for Unclaimed Moneys of Muslims" International Journal of Civil Engineering and Technology (IJCIET), 8/12, (December 2017): 594. 
karşı şükür ve paylaşım, maddi zenginliğe manevi bir zenginlik katmaktadır. Sevgi, merhamet ve mutluluk duygularını besleyerek ebedi bir nimeti kazandırmaktadır. Şükrün zıttı olarak israf, cimrilik, paylaşımın terk edilmesi nimetin yerini manevi bir musibete, korkaklığa ve yalnızlaşmaya bırakmasına sevginin, şefkatin ve insani değerlerin zayıflamasına yol açabilmektedir. Gerçekten hayat varlık ile yokluk, nimet ile musibet arasında yuvarlanan bir süreçtir. Musibet ve yokluk karşısında sabır ve tevekkül; nimet ve varlık karşısında şükür ve paylaşım dengesi kurmak mutlulukla sonuçlanmaktadır. Bu yönüyle İslam iktisat düşüncesi yoksulluğu ve zenginliği manevi açıdan faydalı bir araca dönüştürmektedir.

\section{Toplum bazındaki muhtemel olumsuz sonuçları:}

Fakirlik istismar edilmeye müsaittir. Hz. Peygamber: "Kişinin mümin sabablayarak kâfir olarak geceleyeceüi, kâfir olarak geceleyip mümin olarak. sabahlayacağz ve "dinini dünya karşıliğnnda satacağı" karanlık bulutlara benzeyen fitneler çökmeden önce salih amellerde acele edin" ${ }^{45}$ buyurmakla bu tehlikeye dikkat çekmektedir. Aynı tehlike zenginlik için de söz konusudur. Zira kapitalist anlayış artı değer elde etme uğruna inanç, din ve ahlak gibi temel değerlerden taviz verebilmektedir. Yoksulluğu anarşi, misyonerlik, haksız kazanç ve mafya konularında istismar etmeye çalışanlar yok değildir. Suç oranlarının artmasına, sosyal dışlanmaya, gece kondulaşmaya neden olabilmektedir. Aile içi şiddete, ailelerin dağılmasına, sosyal tabakalaşmaya, tabakalar arası çatışmaya, yağmalama ve anarşiye zemin hazırlayabilmektedir. ${ }^{46}$ Misyonerlik mali yardım vaadiyle fakirliği din değiştirme konusunda istismar etmeye çalışmaktadır. Buna karşı İslam iktisat düşüncesi aldığ1 tedbirlerle insan onurunu yoksulluğun muhtemel olumsuzluklarına, fakirliğin sosyal dışlanmaya yol açmasına veya hakirlik olarak gören bozuk alg1lara (olumsuz yoksulluk kültürüne) karşı korumay1 hedeflemektedir.

\section{Devlet bazındaki muhtemel olumsuz sonuçları:}

Yoksulluğun bir boyutu da devlet bazında fakirliktir. Devlet bütçesinin zayıflaması eğitim, araştırma ve sağlık alanındaki yatırımların

45 Müslìm, Iman, 51.

46 Bkz. Açıkgöz-Yusufoğlu, "Türkiye'de Yoksulluk Olgusu ve Toplumsal Yansimaları", 98-108. 
azalmasına yol açabilmektedir. Sağlık alanındaki yatırımların azalması ortalama insan ömrünü kısaltmaktadır. Eğitim alanındaki yatırımın azalmas1 eğitim kalitesinin düşmesine, bilimsel araştırmaların zayıflamasına ve beyin göçüne yol açabilmektedir. Fakirlikten dolayı dış borçlanmaya gidilmesi, siyasi ve iktisadi bağımsızlığın zayıflamasına sebep olabilmektedir. ${ }^{47}$ Ekonomik krizler bazı toplumlarda kamu düzeninin bozulmasına buna karşıllk kamu otoritesinin sert tedbirler alarak siyasi baskısına yol açabilmektedir. ${ }^{48}$ Bununla birlikte İslam ülkelerinin petrol zenginliğe rağmen teknoloji, sağlık, kalkınma, eğitim ve araştırma alanındaki mevcut durumları bu kapsamda zikredilen sonuçların genelgeçer olmadığını da göstermektedir. Zenginliğe rağmen söz konusu alanlarda geri kalan ülkelerin sayısı az değildir.

Yukarıda arz edilen "yoksulluk" ile "olumsuz sonuçlar" arasında mantıksal açıdan zorunlu bir nedensellik ilişkisi (mülazemet) bulunmamaktadır. Zira yoksulluğa karşı önlem alınmadığı takdirde olumsuz sonuçlara yol açabilmektedir. Önlem alındığında ise olumsuzlukları bertaraf edilmektedir. Fakirlik giderilinceye kadar bireysel, toplumsal ve psikolojik açıdan manevi bir firsata dönüşmektedir. Aynı durum "zenginlik" ile "itraf” kavramları için de geçerlidir. Zenginlik hayırseverlerin elinde cömertlik, şecaat, yardımlaşma, merhamet ve paylassım kapsamında faydalı bir araca dönüşmektedir. Dini, ahlaki ve hukuki açıdan bir firsata dönüştürülmeyince itraf, azgınlık, cimrilik, korkaklık ve yoldan çıkmayla sonuçlanabilmektedir. Fakirliğin veya zenginliğin arz edilen tablodan farklı sonuç bakımından ara derecelerinin, bir diğer ifadeyle gri tonlarının bulunduğu da bir gerçektir.

\section{Tedbirler}

4. İslam İktisadında Yoksulluk Olgusuna Karşı Alınan

\section{1. İslam İktisat Düşüncesinde Yoksulluğun Etik Boyutu}

İslam iktisat düşüncesinde yoksulluğa karşı yoksulların onuru rencide edecek türden olumsuz bir alg1 söz konusu değildir. Fakirlik

47 Robert Lucas, "Expectations and the Neutrality of Money", Journal of Economic Theory, 4/1, (1972): 103-124; Usame Sadık Tayyib v.dğr., Mukâfehatu'l-fakr, 93; Karadâğ̂̀, el-Medhal ila İktisadi'l-İslamî , 1: 254-256.

48 Karadavî, Muskkiletu'l-fakr, 13-18; Karadâğ̂̀, el-Medhal ila iktisadi'l-İslamî , 1: 252-264. 
olgusu önlem alındığı takdirde işlevsel faydalı hale getirilerek bertaraf edilmesi ve muhtemel olumsuz sonuçlarına karşı bireyin korunduğu bir süreçtir. Allah Teâlâ: "Andolsun ki sizi açlı, korku, mallarmı̨dan ve canlarmædan eksiltmek türünden seylerle smayacağrq, sabredenleri müjdele" buyurmuştur. (Bakara, 2/155). Buna göre yoksulluk etik değerler çerçevesinde insan onurunun korunması gereken bir imtihan sürecidir. İslam iktisadı yoksulluğun giderilmesi için birey, toplum ve devlet bazında maddi/manevi tedbirleri almaktadır. Buna bağlı olarak tarih boyunca İslam medeniyeti yoksullara, yetimlere, mazlumlara ve zayıflara kucak açarak onların sığınağı olmuştur. Nitekim Mekke müşrikleri İslam'in fakirlere, kölelere, kadınlara ve zayıflara değer vermesinden rahatsız olmakta ve iman etmemelerini Hz. Peygamber'in etrafindaki fakirlere bağlayarak onları etrafindan kovmasını istemekteydiler. Müşriklerin yoksulluk etrafinda oluşturdukları bu kültür, olumsuz alg1 ve tutumlar şöyle kinamıştır: "Sabah akşam Rablerinin maasm dileyerek O'na yalvaranlarla beraber sen de sabret. Dünya hayatınn güzelliklerini isteyerek gözllerini o kimselerden ayırma. Biฉ̨i anmasın kendisine unutturduğumuz ve işinde aşır giderek, hevesine uyan kimseye uyma" (Kehf, 28/18).

Yoksulluğun zıddı olan zenginlik ise dünya ve ahireti imar etmek için verilen bir nimet, insanoğlunun varlıkla imtihanı, şükür ve paylaşımı gerektiren bir süreçtir. ${ }^{49}$ Ayette zenginlik nimet olarak zikredilmiştir: "Rabbin seni fakir bulup da zenginlesstirmedi mi?" buyrulmuştur. (Duhâ, 93/8). Hz. Peygamber: "İi bir mal, salih bir insann elinde ne güzel bir imkânder" 50 sözüyle bu gerçeğe dikkat çekmiştir.

Buna göre yoksulluk aslında zengin ve fakirin birlikte sinandığ1 bir süreçtir. $\mathrm{Bu}$ süreçte insan onuru yoksulluğa karşı korunmakta, insanoğlu fakirliğe karşı çalışmaya teşvik edilmektedir. Çalışma imkânı olmayanlar nafaka, paylaşım ve beytu'l-mal tedbirleriyle güvence altına alınmaktadır.

\section{1. İslam İktisadının Yoksulluğa Karşı Aldığı Tedbirler}

İslam iktisadını teori, pratik ve hüküm bakımından diğer iktisat teorilerinden ayıran temel özelliği onun vahiy-içtihat ve maslahat

49 Bkz. Karadavi, Muskiletu'l-faker, 13.

50 Muhammed b. Hibban b. Ahmed, Sabîhu İbn Hıbbân, (Beyrut: Müessesetu'r-Risâle, 1993), 4: 8. 
merkezli olmas1, ${ }^{51}$ manevi ve insani değerleriyle temayüz etmesidir. Beşeri iktisat teorilerinden farklı olarak, yoksulluğa karşı sadece dünyevi tedbirler almakla yetinmemektedir. Bu konuda vahiy merkezli olmak üzere inanç, ahlak, ibadet, din, hukuk, siyaset ve iktisat bütünlüğü çerçevesinde tedbir almaktadır. Böylece insan onurunu, aileyi, toplumu ve devleti yoksulluğun olumsuz sonuçlarına karşı korumaktadır. Yoksulluğa karşı bireye, topluma ve devlete dünyevi ve iktisadi tedbirleri alma sorumluluğunu yüklemektedir. Bu açıdan yoksulluk karşısında dini ve dünyevi olmak üzere iki boyutlu iktisadi bir alternatif sunmaktadır.

Şüphesiz yoksulluğa karşı kapitalizmin en iyi çözüm aracı olduğunu iddia eden kuramlar da bulunmaktadır. ${ }^{52}$ Ancak istatistiki veriler, batı medeniyetinin felsefi temellerinden beslenen kapitalizmin küreselleşmesiyle birlikte orta sınıfın zayıfladığını, zengin ve fakir kutuplaşmasının hızlandığını, aradaki uçurumun derinleşerek insanlığı tehdit edecek boyutlara ulaştı̆̆ını göstermektedir. ${ }^{53}$ Kapitalist sistem faiz yoluyla marjinal bir eliti zenginleştirmektedir. ${ }^{54} \mathrm{Bu}$ sistem artı değeri esas alarak az ücretle çok çalıştırabilmekte, emeğin karşıllı̆̆nı geciktirebilmektedir. Kapitalist ahlakın artı değeri kutsallaştırması faiz, sigortasız çalıştırma, inşaat sektöründe malzemeden kısma ve iyiliği artı değer için araç haline getirme türünden problemlere yol açabilmektedir. Kapitalist anlayış artı değer kapsamında sermayeyi sürekli arttırmayı hedeflerken, sermayenin azalmasını önlemek üzere dini, insani ve hukuki bir ödev olarak paylaşım duygusunu zayıflatmaktadır.

Yoksulluğa karşı çözüm üretme iddiasında olan sosyalist düşünce ise kapitalizmin derinleştirdiği tabakalaşma karşısında toplumları emek ve sermaye çatışmalarına sürüklemiştir. Yoksulluk problemine karşı özel mülkiyeti inkâr etme, emek ve sermayede mutlak eşitlik türünden insan

51 Nebhânî, Nizâmu'l-iktisadîfi'l-İslam, 54.

52 Bkz. Francis Fukuyama, Taribin Sonu ve Son Insan, (İstanbul: Profil Yay., 2014), 499.

53 Bkz. Bozan, "Yoksulluk Algısına Farklı Bir Bakış", 391; Reşat Açıkgöz-Ö. Şükrü Yusufoğlu, "Türkiye'de Yoksulluk Olgusu ve Toplumsal Yansımaları", İnsan ve Toplum Bilimleri Arastırmalar Dergisi, 1/1, (2012): 89; Yüksel Çayıroğlu, "İslam İktisadının Karakteristik Özellikleri”. Islam Hukuku Araștırmalar Dergisi, 24/1 (2014): 149-183, 151.

54 Daşlı, "Yoksullukla Mücadelede Yeni Bir Yaklaşım: İşlevsel Yoksulluk", 464. 
fitratına, eşyanın tabiatına ve sosyolojik realiteye aykırı bir ideolojiyi esas almaktadır. Bu sebeple mensubu olduğu toplumlarda anarşiyi tırmandırmış, eşyanın tabiatına aykırı olduğundan bu toplumlarda tutunamamıştır. Sosyalist mutlak eşitlik düşüncesi, toplumsal cinsiyet eşitliği türünden iddialarla insan fitratının tahrip ederek aile kurumuna zarar verdiği gibij ${ }^{55}$ ekonominin tabiatına/fitratına aykırıdır. Kapitalist sistemde zengin bir elit tarafından üretim çarkı haline getirilerek yoksulluğa mahkum edilen bireyler, sosyalist sistemde mülkiyet, emek ve sermaye konusunda mutlak eşitlik iddiasıyla üretim çarkına dönüşmektedir. $\mathrm{Bu}$ yönüyle kapitalizm bireyin menfaatini toplumun menfaatinden üstü tutmaktadır. Sosyalizm ise toplumun menfaatini bireyin menfaatinden üstün tutmaktadır. Biri toplumu bireye feda ederken, diğeri bireyi topluma feda etmektedir. ${ }^{56}$

İslam iktisadı her iki sistemden farklı olarak insanı merkeze alarak onu yoksulluğa karşı korumaktadır. İnanç ve fikir bazında, mali ibadetlerle, mali kefaretlerle ve hukuki tedbirlerle önlem almaktadir. Yoksulluğa karşı alınan maddi paylaşım tedbirleri İslam iktisadında اعوردة zenginliğin/servetin yeniden dağılımı (wealth redistribution) kavramılla ifade edilmiştir. ${ }^{57} \mathrm{Bu}$ dağıtım zorunlu ve gönüllü kısımlara ayrilmaktadır. Nafaka, zekât, fitır sadakası, miras, nezir ve kefaret türünden dağıtım araçları vacip zorunlu kısma dahildir. Sadaka, hibe, vasiyet ve karzı hasen gibi dağıtım araçları nafile bir ibadet olarak gönüllülük kapsamına girmektedir. Devlet hazinesinin yol, köprü, hastane ve okul türünden yatırımları; maaşlar, sosyal yardımlaşma fonu veya burs türünden aldığ 1 tedbirler de yeniden dağıtım kapsamına girmektedir. ${ }^{58}$ Fakirliğe karşı maslahat kapsamında ticaret, ziraat ve sanayi alanlarında çalışarak üretmek dünyevi ve iktisadi tedbirleri almak emredilmiştir. ${ }^{59}$

55 Saffet Köse, Genetiğgyle Oynanmuş Kavramlar ve Aile Medeniyetinin Sonu, (Konya: Mehir Vakf1 Yayınları, 2015), 30-35.

56 Karadavî, Muskiletu'l-faker, 10-11; Tarîkî, el-İktisadu'l-İslamî, 30, 33; Tak1yuddin Nebhânî, en-Nizâmu'l-iktisadî fi'l-İslam, (Beyrut: Dâru'l-Umme, 2004), 39; Karadâğî, el-Medhal ila İktisadi'l-İslamî, 1: 224-226.

57 Bkz. Dwi Retno Widiyanti, "Redistribution Adjusts Efficiency In Economy; Islamic Paradigm" Global Journal of Business and Social Science Review, 3/1, Nowember 2015): 173-174.

58 Misrî, Usûlu İktisâdi'l-İslâmî, 299.

59 Kutup, İslam'ın Dünya Görüsü̈, 195; Bkz. Tahir b. Aşur, Mekasidu'ş-şseriati'l-Islâmiyye, 
Buna ek olarak sevgi, yardımlaşma ve kardeşlik gibi ilkeler İslam iktisadının yoksulluğa karşı insani/ahlaki cephesini oluşturmaktadır.

\subsection{1. İtikadi ve Fikri Tedbirler}

İslam iktisadının bireysel, toplumsal düzlemde yoksulluğa karşı aldığı önlemlerin başında itikadi/fikri tedbirler gelmektedir. Zira her medeniyet olumlu olumsuz yönleriyle kurucu bir inanç, ideoloji ve fikirden doğmaktadır. Eser varlık kazanmadan önce düşüncedir ve aslında düşüncenin somut bir forma bürünmüş halidir. ${ }^{60}$ İktisadi düzenlerin tamamı da kurucu bir felsefeye dayanmaktadır. İslam iktisat düzeni, bu düzen içinde yoksulluğa karşı alınan tedbirler de özü itibarıyla kurucu bir düşüncenin somut forma büründürülmüş halidir. Fakirliğe karşı alınan önlemlerin arka planındaki düşünce şöyle özetlenebilir:

İslam iktisadı düşünce planında mülkiyet Allah’a mahsustur. ${ }^{61} \mathrm{~Hz}$. Peygamber (sav) alemlere rahmet olarak gönderilmiştir. İktisat/ekonomi düzleminde onun insani değerleri merkeze alan ekonomi ahlakı örnek alınmalıdır. ${ }^{62}$ Mülkiyet insana emaneten verilmiştir. İnsanoğlu mülkiyetin varlığ1 yokluğuyla sinanmaktadır; ahirette bu mülkiyetten hesaba çekilecektir. ${ }^{63}$ Özel mülkiyette sinırll1ık, hukukilik ve paylaşım esastır. Yeryüzündeki iktisadi kaynaklar özü itibarıyla tüm insanlığa yeterlidir. Allah Teâlâ bu kaynakların işletilerek geçimin sağlanmasını emrederken, çeşitli sebeplerden yoksulluğa giriftar olanlara zenginlerin mallarında bir hak belirlemiştir. Paylaşım yoluyla iktisadi kaynakların dengeli bir şekilde dağılmasını emretmiştir. ${ }^{64}$ Kaynakların üretim ve dağılımı doğru yapılacak

(Dımaşk: Dâru'l-Kalem, 2016), 475-476; Abdusselam Hareşî, Fıkhu'l-fukarâi ve'lmesâkîn, (Beyrut, Dâru'l-Müeyyed, 2002), 304-309.

60 Ramazan Gürsel Uçar, Düsünmeye Akletmeye Davet, (İstanbul: Mevsimler Kitap, 2018), 15.

61 "Yerlerin ve göklerin mülkiyeti Allab'a mabsustur." (Nur, 24/42).

62 "Biz, seni ancak alemlere rahmet olarak gönderdik." (Enbiya, 21/107). "De ki: "Allah'ı seviyorsanı bana uyun. Allah da siz̨ sevsin ve günablarmı̨ bağzşlasın. Allah affeder ve merhamet eder". (Âli İmran, 3/31).

63 "Dünya hayatında geçim kaynaklarm aralarnda biz.paylaștırdı ve bir kısm diğer kısmma is gördürmesi için, onlarn baz̨larm diğerlerinden derecelerle de üstün kaldık”" (Zuhruf, 43-32). "Bilin ki mallarmz ve cocuklarmz ancak bir fitnedir" (Enfal, 8/28).

64 “(Allab) yeryüzünde bolluk ve bereket yaratt, dört günlük (bir evre ve mevsim) içinde talep 
olursa fakirlik sorun olmaktan çıkar. Kaynak üretimi çalışma, üretme ve kazanma esasına dayalıdır. Kaynak dağılımı çalışarak kazanmanın yanı sıra, kazanılanı yeniden paylaşmak suretiyle gerçekleşmektedir. ${ }^{65}$ Malların batıl yollarla yenilmesi ve kaynakların israf edilmesi yasaklanmıştır. İslam iktisadı dinin inanç, ibadet, ahlak, hukuk boyutlarıyla iç içedir. Özü itibarıly iyiliği, evrensel insani değerleri, insan onurunu korumay1, merhameti ve paylaşım ahlakını esas almaktadır.

Çalışma, azim, gayret, tevekkül, üretim ve paylaşım ahlakı esas alınmışır. Tembellik ve cimrilik yasaklanmıştır. Hz. Peygamber'in "Allab'ım acizlikten, tembellikten, cimrilikten, korkakliktan, borc sikintısindan sana sığmmrm" "şeklinde duasında tembellik, borç ve cimrilik vurgusu ön plana çıkmaktadır. Tembellik fakirin çalışmasına, cimrilik ise zenginin paylaşımda bulunmasına engel olmaktadır. Ayette: "Onlarn yijyeceği, giyeceği, örfe uygun olarak babaya aittir" ${ }^{67}$ buyrulmuştur. Nafakanın vacip k1lınmas1 mükellefin onu karşılamak üzere çalışmanın vacip olmasını gerektirmektedir. Zira vacibin kendisiyle tamamlandığ1 şey -güç yetirilebilir cinsten ise- vaciptir. ${ }^{8} \mathrm{~Hz}$. Peygamber "doğru sözlü, dürüst ve güvenilir tacir, nebiler, siddiklar ve sehitlerle beraberdir" ${ }^{69}$ sözüyle ticarete; "bic kimse elinin emeğinden daha hayırh bir șey yememistir. Allab'ın peygamberi Davut da elinin emeğinden yerdi" buyurmakla fakirlik karşısında emeğe teşvik etmiştir. "Müslüman bir kişi bir ağaç diker veya ekin eker de ondan insan, hayvan veya kus yerse, bu yenen şey kiyamete kadar o kimseye sadakadır" sözüyle tarıma teşvik etmektedir. ${ }^{71}$ Tüm bunlar İslam toplumunu ticaret, tarım ve sanayi alanlarında çalışarak üretmeye ve kazanmaya teşvik etmektedir. İslam düşüncesinde özüyle ve sözüyle güvenilir müslüman tacir, ibadete

edenler için rą̧klarm yeterli/ dengeli bir şekilde takdir etmistir." (Fussilet, 41/10).

"Mallarnda, mubtaç ve yoksullar için bir hak vard." (Zariyat, 51/19). "Namaz killn, zekât verin" (Bakara, 2/43). "Namaz bitince yeryüzüne yayıln; Allab'ın lütfundan rǫ?k isteyin" (Cuma, 62/10). "Insan için ancak çalustiğ vardir." (Necm, 53/39).

66 Buhâri, Et'rme, 28.

67 Bakara, 2/233.

68 Ali b. Ebi Ali b. Muhammed Seyfuddîn el-Âmidî, el-İhkâm fî usûli'l-abkâm, (Beyrut: Daru'l-Kutubi'l-'İlmiyye, 1999), 1: 97.

69 Tirmizî, Buŷ̀', 4.

70 Buhârî, Buŷ̀', 15.

71 Müslim, Musâkeat, 10. 
adanan bir abidden üstündür. ${ }^{72}$ İslam hukukçuları kendisini yalnızca ibadete adayanın zekât hak etmediğini, ancak ilme adayanların zekâtı hak ettiği görüşündedir. ${ }^{73}$

İslam toplumunun iç sorunlarına karşı zihniyet planında yapıcı bir yöntem esas alınmıştır. İç politika ve dış politikada asıl olan barıştır. Dış politikada savaş vatan, din, ilayı kelimetullah ve zulmü ortadan kaldırmak üzere devlet kararına bırakılmıştır. ${ }^{74}$ İç ve dış politikadaki bu yaklaşım fakirlik sorununun anarşi/savaş ve istikrarsızlık türünden kaynaklarını ortadan kaldırmayı hedeflemektedir. ${ }^{75}$ Günümüz İslam toplumlarında ayaklanmalar din, can, mal, nesil ve namus güvenliğini tehlikeye atmaktadır. Bu durum iç istikrarsızlık, düşman işgali, sömürü, fakirlik, yoksulluk ve açliktan ölüm türünden daha büyük sorunlara kaynaklık etmektedir. Bu sebeple İslam toplumunun iç sorunlarına karşısı ıslah, irşad, iyiliği emretme kötülüğü yasaklama türünden yapıcı bir zihniyetin esas alınması daha isabetlidir. ${ }^{76}$

İnsanoğlunun açlık, korku, can ve maldan eksiltmeyle sınanacağ1, sabredenlerin kurtulacağı, her zorlukla birlikte bir kolaylığın bulunduğu bildirilmiştir. (İnşirah, 94/5). "(Onlar) darlketa, hastalkta ve savas zamannda sabrederler. İste doğru olanlar bunlarder ve takvâ sahipleri bunlardır." (Bakara, 2/177). Hz. Peygamber: "Birinizin sirtında bir bağ odun tasıyarak satması ve geçimini sağlaması, başkalarndan dilenmesinden, onlarm da istediğini vermesinden ve vermemesinden daha hayırlıdır" buyurmuştur. ${ }^{77}$ Bu kapsamdaki naslar fakirlik sorununa karşı sabırla direnmeyi, onun zararlarını önlemeyi hedeflemektedir.

Uluslararası alanda fakirliğin kaynaklarından biri olan sömürgecilik faaliyetleridir. Bu faaliyetlere karşı birey, toplum ve devlet bazında meşru müdafaa hakkı tanınmıştır. Bu hak İslam hukuk

\footnotetext{
Karadâvî, Muşkiletu'l-faker, 44.

Karadâvî, Fıkhu'r-zekât, 379.

74 Ahmet Yaman- Halit Çalış, İslam Hukuku, (Ankara: Bilay Yay., 2018), 151-152.

75 Karadâğ̂̀, el-Medhal ila iketisadi'l-İslamî, 1: 272.

76 Bkz. Abdulmelik b. Abdullah b. Yusuf el-Cüveynî, “Ğıyasu'l-umem ve teyyasu'z-zulem” (İskenderiye: Dâru'd-Da've, 1979), 88.

77 Buhârî, Zekât, 50.
} 
düşüncesinde abkâmuș'ș-șail/șavlet başlıkları altında ele alınmıştır. ${ }^{78} \mathrm{~Hz}$. Peygamber, "birileri malım almak isterse ne yapayım" diye soran adama "malm ona verme" buyurmuştur. Adam: "benimle savaşırsa ne yapayım?" deyince Hz. Peygamber "sen de onunla savass" demisstir. Adam: "Beni öldürürse?" deyince, Hz. Peygamber "sen șehit olursun" demiștir. Adam: "Peki ben onu öldürürsem ne olur?" diye sorunca Hz. Peygamber: "O atestedir" buyurmuştur. ${ }^{79}$ Meşru müdafaa kapsamında sömürgeciliğe, ekonomik yaptırımlara ve siyasi baskılara karşı devlet otoritesinin siyasi, iktisadi ve idari alanlarda önlem alması "zulüm etmeme ve zulme boyun eğmeme" düşüncesine dayanmaktadır. Böylece devlet bazındaki yoksulluğun diş sebeplerine karşı zihniyet bazında önlem alınmıştır.

\subsection{2. İbadet Düzeyinde Alınan Tedbirler}

Mali paylaşıma dayalı farz, vacip ve nafile ibadetler iktisadi açıdan zenginliğin dağılımı kapsamına girmektedir. Bu paylaşım sermayeyi belirli kutuplar arasında dolaşan bir meta olmaktan çıkarma düşüncesine dayanmaktadır. İslam iktisat düşüncesindeki yeniden dağıtımın (wealth redistribution) arka planında da bu düşünce bulunmaktadır.

Nisap miktarı mala sahip olanlar zekât, öşür, fitır sadakası, kurban ve mali nezirleri yerine getirmekle, gayrı müslimler ise haraç ve cizye ile mükellef tutulmuştur. Bununla sermayenin tek elde toplanmasinı önleyerek onu belirli oranlarda paylaşmak ve sosyal adaleti sağlamak hedeflenmiştir. Zekât fonu insanlı tarihinde fakirliğe karşı ilk sosyal güvence ve sosyal sigorta mahiyetindedir. İslam'ın ilk ylllarından itibaren emredilmiştir. $\mathrm{Bu}$ açıdan fakirlikle mücadele ibadet kapsamına girmektedir. Ingiltere ve Amerika'da ise fakirlik karşısında bireylere toplumsal güvence sağlama planı 1941 tarihinde başlatılmıştır. ${ }^{80}$

Zekât toplumsal tabakalar arasında sevgi, saygı, paylaşım, gönül, birlik ve beraberlik köprüsünü kurmaktadır. Fakirin kalbini haset, nefret, isyan, yağmalama ve ayaklanma duygularından temizlemektedir. Bunun yerine sabır, sevgi, kardeşlik, dua ve saygı duygularını güçlendirmektedir. Zenginin kalbini cimrilik, merhametsizlik, kibir ve gurur gibi duygulardan

78 Bkz. Takıyuddin Ebubekir Muhammed b. Muhammed ed-Dımaşkî, Kifâyetu'l-abyâr fî halli ğayeti'l-ibtisâr, (Beyrut, Dâru'l-Hayr, 2004), 583.

79 Müslim, Iman, 125.

80 Karadâvî, Muşkiletu'l-fakr, 105-106. 
temizlemektedir. Bunun yerine şükür, sevgi, paylaşım, cömertlik, tevazu ve kardeşlik şuurunu güçlendirmektedir. ${ }^{81}$

Mali ibadetler yoksulluğun kültür, eğitim, kalkınma ve kamu düzeni planında sorun üretmesini engellemektedir. İslam iktisadında mali paylaşım geniş tabanlı bir mahiyettedir. Örneğin zekât konusunda: "(kendilerine pay düsmeyen) akrabalar, yetimler ve fakirler miras taksiminde hazur bulunurlarsa, onlara da maldan bir şeyler verin ve (gönüllerini alacak) güzel sözler söyleyin." (Nisa, 4/8) buyrulmuştur. Zekât ise sekiz ayrı sinıfa verilmektedir. Buna göre İslam iktisadı geniş yelpazeli bir paylaşım yoluyla refah düzeyini en geniş tabana yaymayı hedeflemektir. ${ }^{82}$ Zekâtın bireysel olarak verilmesi caiz olmakla birlikte kamu otoritesi tarafindan zenginlerden alınarak fakirlere dağıtılması daha uygundur. $\mathrm{Hz}$. Peygamber'in, raşid halifelerin uygulaması da bu yöndedir. Zekât memurlarının varlığı, ayette "onlarn mallarndan sadaka al, böylece onlar temįlemis ve arndirmıs olursun" (Tevbe, 9/103) buyrulması zekâtın fakirlikle mücadele fonu olarak devlet tarafindan etkili bir şekilde issletilmesinin daha uygun olduğunu ifade etmektedir. ${ }^{83}$

Yoksulluk zekât fonuyla mücadele edilmesi gereken bir sorundur. Bu açıdan zekât fonu itikadi, psikolojik, ahlaki, hukuki ve iktisadi birçok amaca hizmet etmektedir. Fakirliğin isyan ve anarşiye dönüşmesini engelleyerek eğitim, kültür ve kalkınma alanlarına katı sunmaktadır. Eğitim araştırma faaliyetleri için mali destek sağlarken gayrı müslimleri İslam'a 1sındirmaktadir.

Şafiî ve Hanbelî hukukçulara göre günlük yiyeceği bulunan, çalışabilecek durumda olmasına rağmen çalışmayan kimselere zekât verilmez. ${ }^{84}$ Hanefi hukukçular böyle bir kimseye zekât verilebileceğini, ancak çalışmasının daha öncelikli olduğunu belirtmişlerdir. ${ }^{85} \mathrm{Bu}$

81 Kâsânî, el-Bedâiu's-sinâî, 3:2; Muhammed b. Ömer er-Râzî, Mefâtihu'l-ğayb, (Beyrut: Dâru İhyai'-t-Turâsi'l-'Arabî, Tsz.), 16: 89.

82 Ahmet Tabakoğlu, "Bir İlim Olarak İslam İktisadı", İslam Hukuku Araştırmalar Dergisi, 16/1, (2010): 250.

83 Bkz. Nevevî, el-Mecmû́; 6: 162.

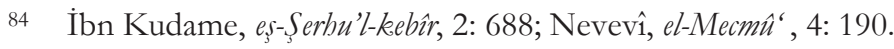

85 İbn Hümam, Fethu'l-kadîr, 2: 282. 
durumdaki bir kimsenin dilenmesi caiz değildir. Durumun farkında olanların böyle bir kimseye zekât vermesi, onun çalışmayarak dilenmesine sebep olacağından caiz görülmemiştir. ${ }^{86} \mathrm{~Hz}$. Peygamber "zenginlerin, güçlï ve çalssacak durumda olanlarn zẹkâtta payn yoktur" buyurmuştur. ${ }^{87}$ Hanefilere göre fakire bir defada nisap miktarı mal vermek mekruhtur. Ancak borçlu olması ve verilen zekâtın yetmemesi halinde bu durum mekruh olmaktan çıkar. ${ }^{88}$ Şafiilere göre fakiri zenginlik sınırının üstüne taşıyacak ve ömür boyu kendisine yetebilecek miktarda zekât verilebilir. ${ }^{89}$ Hanbeli ve Malikîlere göre ise fakire en fazla bir yıl yetecek kadar zekât verilebilir. ${ }^{90}$ Kamu otoritesinin bu iki içtihadî görüşten birini esas alması halinde ulu'lemre itaat kapsamında ihtilaf ortadan kalkacağından, ${ }^{91}$ şartlar muvacehesinde fakirliğe karşı önlem almak üzere bu içtihatlardan en isabetli olanı tercih edilebilir.

Ticari mallar, altın, gümüş, para, ehli hayvanlar, madenler, tahıl ürünleri, ekin ve meyveler yıllık olarak zekâta tabidir. Nisaba ulaşan hisse senetleri, maaş, serbest meslek kazançları kırkta bir (\%2.5) oranında zekata tabidir. ${ }^{92}$ Zekât devlet tarafindan alınarak fakire verilen sosyal yardımlaşma fonu mahiyetinde toplumsal bir ibadettir. Geçmişte olduğu gibi günümüzde de devlet desteğiyle zekât fonunun açılması ve usulüne uygun bir şekilde işletilmesi fakirliği önemli ölçüde azaltacaktır.

Oruç sayesinde nimetin değeri anlaşılmakta vicdanlara şükür, sabır, merhamet ve empati değerleri yerleştirilmektedir. Açlık ve yoksulluğun ne olduğu idrak edilmektedir. Bunun akabinde mali bir ibadet olarak fitır sadakası emredilmektedir. İki ay sonra Kurban Bayramında kurban kesilerek dağıtılması emredilmektedir. Kapitalist veya sosyalist iktisat düzenlerinde zekât, sadaka ve kurban türünden mali paylaşımlar bulunmamaktadır. Kapitalist sistemler bu boşluğu sosyal yardımlaşma fonu, sosyal güvence ve sigortalar vasıtasıyla doldurmak

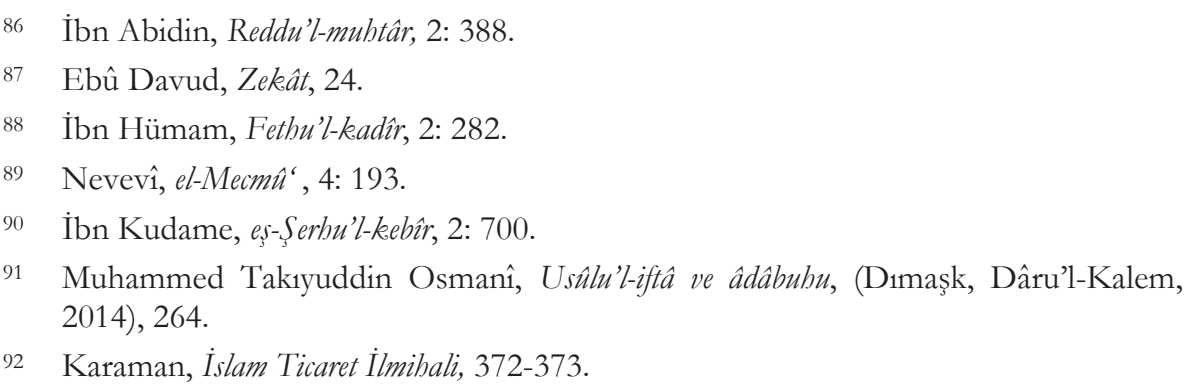


zorunda kalmıştır. $\mathrm{Bu}$ uygulamalar doğrudan birey-devlet merkezli olduğundan, bir kısmı ticari olduğundan zengin ile fakir arasında sevgi, sayg1, merhamet, dayanışma, birlik-beraberli ve paylaşım bağını yeterince kuramamaktadır. Ekonomik açıdan güçlü olan kapitalist bazı sistemler fakirlik sorununu maddeten çözmüşlerdir. Bunu konuda sömürgecilik faaliyetlerinden elde edilen gelirler göz önüne alınmalıdır. Öte yandan İslam iktisat düşüncesinin tarım, ticaret ve sanayileşme alanında aldığ maddi tedbirleri yerine getirmişlerdir. Kendi toplumlarında fakirlik sorununu çözmekle birlikte, istatistik araştırma raporları kapitalizmin küresel çapta yol açtığı yoksulluk felaketinin boyutlarını ortaya koymaktadır.

İslam Hukukçularının büyük çoğunluğuna göre malda zekât dışında bir mükellefiyet bulunmaz. ${ }^{93}$ Çünkü Hz. Peygamber "zekât dışında mali bir sorumluk var midir" sorusuna "hayur, sadaka olarak fąladan vermen hariç yoktur" buyurmuştur. ${ }^{94} \mathrm{Bu}$ delilden zekât dişındaki mali ibadetlerin farz olmadığ1 anlaşılabilir. Ancak bu durum diğer mali mükellefiyetlerin farz, vacip veya sünnet kısımlara ayrılmasına engel değildir. Çünkü malda zekâtın dişında fitır sadakası, kurban, nafaka ve mali kefaret türünden yükümlülükler de bulunmaktadır. Sahabeden $\mathrm{Hz}$. Ömer, Hz. Ali, Hz. Ayşe ve Hz. Ebu Hüreyre'den malda zekât dışında da mali mükellefiyetlerin bulunduğu aktarılmıştır. ${ }^{95}$ Allah Teâla zekâta ek olarak "sevdiklerinizden harcamadıkşa iyiliğe ulaşamąssmı" buyurmuştur. (Âl-i İmran, 3/92). Buna göre malda zekât dişında da mali bir mükellefiyet bulunmaktadır. Zekât, fitır sadakası, nafaka, kurban gibi ibadetleri yerine getirenlerin mali sorumluluğu yerine getirmiş olacağında şüphe yoktur. Ancak İbn Hazm'a göre zenginler genel anlamda fakirlerin ihtiyacinı gidermekle sorumludur. Bir mahallede açlıktan ölen kimsenin diyetinin o mahallenin tamamına ödetilir. Öte yandan fakirliği gidermek için zekât yeterli değilse devletin ek vergilerle bu ihtiyacı karşılama hakkı vardır. ${ }^{96}$

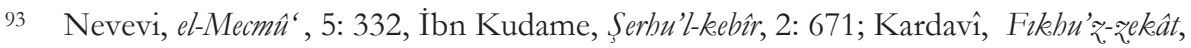
646.

94 Buhârî, Iman, 3.

95 İbn Hazm, el-Muhalla, 4: 281; Kardavî, Fıkhu'r-zekât, 649.

96 İbn Hazm, el-Muhalla, 4: 281-283; Kutup, İslam'in Dünya Görüsüu, 197; Bkz. Karadavi, Fıkhu'z-zekât, 646-665; Karaman, İslam Ticaret Ilmihali, 351. 
İnfakı emreden nasların genel çerçevesinden hareketle, devletin fakirlikle mücadele etmek üzere zekât dışında ek vergiler belirleme hakkının bulunduğunu teslim etmek daha isabetlidir.

\subsubsection{Mali Kefaret Düzeyinde Alınan Tedbirleri}

Yemin bozma, zıhar, orucu kasten bozma, yaşlılık veya hastalık sebebiyle oruç tutamama veya ihram yasağı işleme durumlarında kefaret vermek emredilmiştir. Bu konudaki kefaretler duruma göre köle azat etme, mali kefaret veya oruç türünden kısımlara ayrılmaktadır.

Yemin kefaretiyle ilgili olarak "Yeminin kefareti, ailenize yedirdiğinizin ortalamasindan on düskünü yedirmek yahut giydirmek ya da bir köle azad etmektir. Bulamayan üs gün oruc tutmalidrr. Yeminleriniz̨in kefareti budur." buyrulmuştur. (Maide, 5/85). Ziharla ilgili olarak: "(Köle ąat etme imkân) bulamayanlar, eşine dokunmadan önce art arda iki ay oruç tutmalidrr. Buna gücü yetmeyen altmış fakiri doyursun" buyrulmuştur. (Mücadele, 58/4). Bu kapsamdaki hükümler nefis terbiyesinin yanı sıra köleliği ortadan kaldırmayı ve mali açıdan fakirlik sorununu zayıflatmayı hedeflemektedir. Zihar kefaretinde ve orucu kasten bozmanın kefaretindeki köle azat etme, altmıs fakiri doyurma seçenekleri insanoğluna kölelikten kurtularak özgürlükle onurlanmasını amaçlamaktadır. Mali kefaretler, mükellefi eğitmenin yanı sıra yoksullukla mücadele etmek üzere birer yardımlaşma arac1 mahiyetindedir. Can güvenliğini sağlamak üzere kasten öldürme karş1 suçuna karş1 kısas, diyet ve af hatayla öldürme durumunda ise diyet ve af alternatifleri sunulmuştur. ${ }^{97} \mathrm{Bu}$ durum maktulün mirasçılarını iktisadi açıdan korumaktadır. Hatayla öldürmede akılenin diyete dahil edilmesi iktisadi yardımlaşma amacına matuftur.

\subsubsection{Mali Sorumluluklar ve Teberru Akitleriyle Tedbir}

İslam iktisadı hukuki mali sorumlulukların yanı sıra teberru akitleriyle yoksulluğa karşı önlem almaktadır. Bu sayede zenginliği fakirliğe karşı bir önlem aracına dönüştürmektedir. Nafakanın farz kilınmas1, mirasin emredilmesi buna ek olarak vasiyet, vakıf, hibe, ariyet ve karzı hasen türünden teberru/iyilik akitleri fakirlik sorununa karş1 alınan ahlaki, insani ve hukuki önlemlerdendir. Tüm bunlar aynı zamanda iktisadi servetin yeniden dağılımı kapsamına girmektedir.

97 Bkz. Dimaşkî, Kifâyetu'l-abyâr, 541-542. 
Nafakayı temin etmek hukuki açıdan aile reisi olarak babaya yüklenmiştir. "Onlarn (annelerin) yiyeceği, giyeceği, örfe uygun olarak (mevludun leb olarak)babaya aittir. Hiçbir kimseye gücünün üstünde bir yük ve sorumluluk. teklif edilmex:" (Bakara, 2/233). Öten yandan ayette "Akrabaya, yoksula ve yolcuya hakkem ver, malı saşı savurma” buyrulmuştur. (İsra, 17/26). İslam Hukukçularının şu ifadeleri konuyu aydınlatmaktadır:

"Kadin erkek olsun fark etmez kendisinin, essinin ve çocuklarmm nafakasindan fazla bir mala sahip olan herkes yashluke, hastahk, çocukluk ve delilike gibi bir sebeple çalișamayan ve ibtiyaç sabibi bulunan anne-baba ile dede-ninelerin din farkina bakılmaksızın nafakasm temin etmekle yükü̈mü̈dür. Ayn șekilde bayvanlarn nafakasim karşlamak da bukuki bir sorumluluktur. Nafakayla sorumlu olanlar bu sorumluluğu yerine getirmeyecek olursa, bakim yasal yollarla nafakann tabsil edilmesine bükemeder. Yasal uyarlara rağmen nafaka verilmezse, maln haciz yoluyla müsaderesine ve satılmasina bükmedilir."98 Nafakanın vacip kılınması, nafakayı temin etmek için çalışmayı da vacip hale getirmektedir. Bu durumda gücü yetenler çalışma yoluyla, çalışmaya gücü yetmeyenler nafaka alma yoluyla fakirliğe karşı güvence altına alınmıştır. Çalıştı̆̆1 halde nafakaya güç yetiremeyenler ise zekât fonuyla, devlet hazinesiyle güvence altına alınmıştır.

İslam medeniyeti aynı zamanda bir vakıf medeniyetidir. İyilik, insani yardım ve sadaka-i cariye düşüncesine dayanan vakıflarla yoksulluğa karşı önlem alınmıştır. Selçuklu ve Osmanlı döneminden günümüze yöneticisi kalmayan 52 bin vakıf intikal etmiştir. Vakıf hizmetinden veya menfaatlerinden yararlanabilmek için etnik, dinî, cinsiyet ve sosyal statü şartı aranmamış, hayır hususunda ayrımcılık ve bölgecilik yapılmamıştır. ${ }^{99}$ Vakıflar eğitim, sağlık, şehircilik, bayındırlık ve askeri alanlarda hizmet vermiştir. Vakıflar sosyal tabakalaşmayı, toplumsal çatışmayı, servetin tekelleşmesini önlemiştir. Adil gelir dağılımını sağlamıştır. Toplumsal bütünleșmeye ve vakıf bünyesinde istihdama yardımcı olmuştur. ${ }^{100}$ Örneğin Osmanlı para vakıfları maddi

98 Muhammed Züheyr Ğamravî, Envâru'l-Mesâlike (Midyat: Dâru Nuri’s-Sabah, 2010), 491-492; İbn Kudame, Serbu'l-kebîr, 9: 257-258.

99 https://www.vgm.gov.tr/kurumsal/tarihce/tarihte-vakiflar, Erişim: 11.11.2019.

100 Adnan Ertem, “Osmanlı'dan Günümüze Vakıf Medeniyeti”, Vakıflar Dergisi, 36/1, (Aralık 1999): 36-37. 
sıkıntıs1 yaşayanlara rehin şartıyla karzı hasen kapsamında faizsiz borç vermekle sosyal yardımlaşmanın dini/insani bir tezahürü olarak somutlaşmıştır. ${ }^{101} \mathrm{Bu}$ yönüyle İslam'da vakıf düşüncesi Osmanlı medeniyetine bir "vakıf medeniyeti” ünvanını verdirerek yoksulluğa karşı yardımlaşma modeli olarak dünyaya örnek olmuştur. Öte yandan zimem defterlerini satın alma, sadaka taşları, daru'ş-şafaka, daru'l-aceze, daru'şşifalar, hanlar ve kervansaraylar ihsan ahlakının somut tezahürleridir.

Vasiyet ilk etapta emredilmiş, bilahare miras ayetleriyle vacip olmaktan çıkarak gönüllülük kapsamında varlığını devam ettirmiş ${ }^{102}$ ve mal varlığının üçte biriyle sınırlandırılmıştır. Varisler fakir ise vasiyetin malın üçte birinden az olması müstehaptır. ${ }^{103} \mathrm{Bu}$ durum vasiyeti iyilik ve yardımlaşma amacına dönüştürmekle birlikte, vasiyet durumunda mirasçıların mahrum kalmaması için adil bir dağılım sağlamaktadır. Konuyla ilgili naslar ariyet/ödünç verme, hibe, karz-1 hasen, borçluya zaman tanıma ve alacağı bağışlama türünden insani/ahlaki önlemler almaktadır.

\subsubsection{Maslahat Kapsaminda Alınan Tedbirler}

Yoksulluğa karşı idari, siyasi ve ekonomik tedbirleri almak bireyin, toplumun ve devletin ortak görevleri arasındadır. İslam iktisat düşüncesinde iktisadın üretim, dağıtım, ithalat ve ihracat enstrümanları tümel ve tikel açılardan dini bir boyutun yanı sıra dünyevi boyutlara da sahiptir. Dünyevi açıdan her türlü iktisadi tedbiri alma maslahat kapsamına girmekte ve ilkesel bazda dinin sinırlarına dahil olmaktadır. Bir diğer ifadeyle fakirliğe karşı teşriî şeriat (din) ile tekvini şeriat (sünnetullah) birlikteliği esas alınmıştır. Örneğin üretim konusunda ziraat, ticaret ve sanayileşme emir ve teşvik edilmiştir. Bunun dünyevi boyutlar1 ise maslahat kapsaminda bireye, topluma ve devlete bırakılmıştır. İktisadi açıdan çözüm üretme, vergi alma, ekonomik kalkınma planları yapma, fakirlik sorununa karşı sivil toplum kuruluşlarıyla işbirliği yapma da bu türdendir. ${ }^{104}$ Bu kapsamda kamu

101 Murat Çizakça, Osmanh Dönemini Tarihsel ve Ekonomik Boyutlar, 24-25.

102 Muhammed b. İdris eş-Şafî, er-Risale, (Beyrut: Daru'l-Kutubi'l-İlmiyye, 2005), 160161.

103 Nevevî, el-Mecmû', 15: 402.

104 Karaman, İslam Ticaret İmihali, 361; Bkz. Misrî, Usûlu'l-ik.tisâdi'l-İslamî, 29-31; Fikret Şenses, Küreselleşmenin Öteki Yü̊ü Yoksulluk, (İstanbul, İletişim Yay., 2009), 219. 
sektörü ve özel sektör alanında istihdam alanları oluşturabilir. Üretim, ithalat ve ihracat konusunda iktisat biliminin yanından diğer tüm bilimlerden yararlanılabilir. Özel iktisadi girişimler faizsiz finansmanlarla desteklenebilir. İşsizlik sorununa karşı kurumsal bazda çözümler üretilebilir. Ekonomik kalkınmanın hukuki, idari, iktisadi alt yapısı için gerekli olan düzenlemeler yapılabilir. Çalışsma imkânı bulunmayanların, asgari düzeyde ihtiyaçlarını karşılamaları için mali yardım sağlanabilir. ${ }^{105}$ Beytu'l-mal fakirlerin ihtiyacını doğrudan karşılayabileceği gibi sosyal sorumluluk, iktisadi projeleri (kobileri) destekleyerek istihdam alanı oluşturmak suretiyle yoksulluğa karşı etkin bir fon olarak kullanılabilir. ${ }^{106}$ $\mathrm{Bu}$ tür tedbirler sosyal devlet olmanın bir gereğidir. Bu tür faaliyetler maslahat kapsamında kamu otoritesine bırakılmıştır.

Fakirlik önlem alınmadığ takdirde can, mal, nesil, akıl için zararlı olabilmektedir. Kamu düzeni, devlet bütçesi, eğitim/araştırma faaliyetleri, kalkınma ve sağlık hizmetleri alanında sorun olabilmektedir. Yoksullar sosyal devlet olmanın bir gereği olarak fakirliğin olumsuz sonuçlarına karşı dinin ve devletin güvencesine alınmıştır. ${ }^{107}$ Yoksulluğa karşı maslahat kapsamında alınacak tedbirler din, bilim ve ahlak alanlarının birlikteliğine dayanmaktadır.

\subsubsection{Yoksulluğa Karşı İnsani Değerlerle Tedbir}

İslam iktisadı yoksulluğa karşı ihsan kapsamında infak, îsar, şefkat, merhamet, iyilik ve takva konusunda yardımlaşma türünden temel insani değerleri esas almaktadır. ${ }^{108}$ İslam iktisat düşüncesi insan merkezlidir. Fakirliğe karşı gerek zihniyet, ibadet, hukuki sorumluluk ve teberru akitleri kapsamında alınan önlemler temel insani değerlerle aynı paydada buluşmaktadır.

İslam iktisat düşüncesinde yoksulluk kutsanmamıştır. Yoksulluğun muhtemel zararlarına, olumsuz sonuçlarına dikkat çekilerek, buna karşı önlem alınmıştır. Fakirlik/yoksulluk olgusuna karşı ihsan,

105 Karadâğ̂̀, el-Medhal ila iktisadi'l-İslamî, 1: 280-286; Bkz. Şenses, Küresellesmenin Öteki Ÿ̈гӥ Yoksulluk, 219.

106 Anwar, "Battulmal's Potentral as Trustee for Unclaimed Moneys of Muslims", 595.

107 Karadavi, Muskiletu'l-fakr, 109.

108 Bkz. Öztürk, Kur'ân ve Sünnete Göre Tasavvuf, 211, 215. 
şefkat ve merhamet tabanlı kucaklayıcı bir kültür oluşturmuştur. Yoksulları dışlamadan, ayrımcılık yapmadan, maddi/manevi açıdan şefkat kanatlarının himayesine almıştır. Geçmişten günümüze yoksulluk etrafinda oluşturulan olumsuz, dışlayıcı ve rencide edici algılar İslam iktisat düşüncesiyle bağdaşmamaktadır. İslam iktisat düşüncesi insan onurunu yoksulluk etrafinda oluşturulan olumsuz algıya karşı korumayı hedeflemektedir. İslam'ın yoksulluk karşısındaki ihsan merkezli yaklaşımı tarihi süreçte devlet bazında bir politikaya dönüşmüştür. İhsan düşüncesi teoride kalmayarak zihniyet, ahlak, ibadet ve hukuk planlarında somut bir forma dönüşmüştür.

İslam yoksulluğa karşı yalnızca kendi mensuplarını değil, aynı zamanda tüm insanlığı ortak bir sorumluluk altına almıştır. Zira yoksulluk insanlığın ortak bir problemidir. Nitekim gayrı müslümler haraç, cizye ve diğer vergilerle sorumlu tutulmuştur. Öte yandan müellefe-i kulûba zekâttan pay ayrilırken, İmam Ebu Hanife'nin içtihadına göre fitır sadakası da verilebilmektedir. ${ }^{109}$ Buna göre İslam iktisadı yoksulluk karşısında din, dil, renk ve irk ayrımına gitmemektedir. Hz. Peygamber "komsusu ac iken kendisi tok yatan bizden değildir" buyurmuştur. ${ }^{110}$ Komşunun müslüman olup olmaması konusunda bir ayrıma gidilmemiştir. Hz. Peygamber cahiliye dönemindeki hilfu'l-fudûl uygulamasından övgüyle bahsetmiştir. Mekke'nin fethinden sonra Kureyş'in cahliye dönemindeki ihsan merkezli uygulamaları devam ettirilmiştir. Hz. Ömer gayrı müslimlerden fakir, yaşlı ve çalışamaz durumda olanlara maaş bağlamıştır. ${ }^{111}$ İslam iktisadı fakirlik problemini ihsan temellinde ele almaktadır. İhsan insanoğlunun yanı sıra tüm varlı̆̆1 şefkat, merhamet ve iyilikle kuşatan bir ruhtur. ${ }^{112}$ Her şeyin en güzelini yapmak ve her konuda en iyi olmaya çalışmaktır.

Ayette "Ortak kossanlarm (müsriklerin) vay haline, onlar ki zekât vermez, abirete inanmazlar" (Fussilet, 41/7) buyrulmuştur. Bir başka ayette: "Şimdi yüz çevireni; pek az verip de kaskatı cimrileșeni gördün mü??" (Necm, 53/34) buyrulmuştur. Buna göre tüm insanlık iman etmekle mükellef olduğu kadar paylaşımla da mükelleftir. Sivil toplum kuruluşları, ulusal ve

109 Bkz. İbn Rüşd, Bidayetu'l-Müctehid, 260.

110 Beyhakî, es-Sünen, 10: 5 (19668).

111 Bkz. Öztürk, Kur'ân ve Sünnete Göre Tasavvuf, 211, 215, 226.

112 Bkz. Öztürk, Kur'ân ve Sünnete Göre Tasavvuf, 226. 
uluslararası yardım kuruluşları İslam'ın iktisat düşüncesinde ihsan ilkesinin kapsamına girmektedir. İslam iktisat düşüncesi bu konuda şeffaflı̆̆1, hesap verebilirliği, politik istismarlardan uzak bir samimiyet vasatını esas almaktadır. Allah Teâla "Ana-babaya, yakınlara, yetimlere, yoksullara, yakin komsunuza, urak komsunuza, yolda kalanlara, elinizin altındakilere iyilike yapmanı̨? emretti" buyurmuştur. (Nisa, 4/36). Cehennemlikler için "bir. namaz. kelanlardan ve yoksullar doyuranlardan değildike" (Müddesir, 74/44) buyrulmaktadır. Bu ayetlerde yoksulların dini, dili, rengi ve memleketi konusunda bir ayrıma gidilmemiştir. Fakirlerin borcunu ödemek üzere zimem defterlerinin bilinmeyen hayır sahipleri tarafindan satın alınması, sadaka taşlarında ihtiyaç sahipleri için hayır sahipleri tarafindan birakılan maddi yardımlar bunun bir tezahürüdür. $\mathrm{Bu}$ yaklaşım özü itibarıyla Hz. Peygamber'in "ciğer tassyan her canl için (yapılan iyilikte) sevap vardrr" şeklinde özetlemisstir. (Buharî, Musakât, 9). Buna bağlı olarak İslam tarihinde yalnızca insanlı̆ın yanı sıra varlığın tamamı ihsan, şefkat ve merhamet kanatlarının himayesine alınmıştır.

\section{Sonuç}

Yoksulluk birey, toplum, ülke ve dünya bazında maddi manevi boyutları bulunan bir olgudur. İslam iktisat düşüncesinin fakirlik olgusuna yaklaşımı beşeri iktisat düşüncelerinden farklılaşmaktadır. Kaynak bakımından vahiy ve içtihat merkezli olup inanç, ahlak, ibadet, hukuk ve maslahat bütünlügüne dayanmaktadır. Böyle bir bütünlük içinde yoksulluğa ve olumsuz sonuçlarına karşı önlem almaktadır. Kendi mensuplarının yanı sıra tüm insanlığa bu konuda görev ve sorumluluk yüklemektedir.

Yoksulluğun sebepleri ve sonuçları bir toplumdan diğerine farklılaşmaktadır. Önlem alınmadığı takdirde yoksulluk birey, toplum ve devlet bazında olumsuz sonuçlara yol açmaktadır. İslam İktisat düşüncesinde fakirlik problemine karşı alınan tedbirler dini ve teşriî, dünyevi ve tekvînî olmak üzere iki boyutludur.

1. Teşrî̀ irade kapsamında yoksulluğa karşı inanç, fikir, ahlak ve zihniyet planında önlem alınmıştır. İkinci olarak mali ibadetler, kefaretler, nezirler ve sorumlulukların yanında vakıf, karzı hasen ve hibe türünden iktisadi araçlarla yoksulluğu giderilmesi amaçlanmıştır. İbadet, hukuk, ahlak ve iktisat bütünlüğ̈ne dayanan bu tedbirler, ihsan kapsamında şefkat, merhamet, adalet ve paylaşım gibi temel insani değerlerin somut 
formlarıdır. Yoksulluğu bertaraf etme gayesi de ancak bu formlarla gerçekleşebilir. İslam iktisadı farz, vacip ve sünnet düzeyindeki bu formlar sayesinde, sermayeyi zenginlerin elinde dolaşan bir meta olmaktan çıkararak toplumun tamamına yaymayı amaçlamaktadır. Bir diğer ifadeyle dinin belirlediği iktisadi paylaşım yollarıyla zenginliği insanlık için faydalı bir araca dönüştürmeyi hedeflemektedir.

2. Tekvinî irade kapsamında yoksulluğa karşı ticaret, tarım ve sanayi alanlarında çalışarak üretmeyi; yoksulluğa karşı ekonomik, bilimsel, teknolojik, siyasi ve idari önlemlerin alınması gerekmektedir. İslam dünyası yoksulluğa karşı teşri iradenin gereklerini kısmen yerine getiriyor olsa da tekvini iradenin gereklerini yeterince yerine getirmemektedir. Gayr1 müslim toplumlar tekvini iradenin gereklerini yerine getirmek suretiyle kendi içinde maddi yoksulluğu zayıflatmıştır. Ancak bir taraftan toplumu manevi yoksulluğa mahkum ederken, diğer taraftan kapitalist sömürgecilik yoluyla küresel bazda yoksulluğu derinleştirmiştir.

İslam iktisadı bireysel bazda yoksulluğa karşı sabır, kanaat, çalışma ve tevekkül zihniyetini yerleştirmekte; tembelliği, cimriliği ve fakirlik korkusunu ise kınamaktadır. Bireyin çalışma imkanı yoksa veya çalışmasına rağmen yoksul ise bu durumda yoksulluğa karşı infak/paylaşım yoluyla tedbir alınmıştır. İnfak ise farz, vacip ve nafile kısımlara ayrilmaktadır. İnfak kapsamında nafaka, zekât, fitır sadakası, mali kefaretler, nezirler ve nafile sadakalarla önlem alınmaktadır. Buna ek olarak vakıf, vasiyet, miras, borç verme, hibe, ariyet/ödünç ve komşuluğun gerektirdiği mali sorumluluklar1 yerine getirme türünden iyilik esasına dayalı tedbirler alınmaktadır. Maslahat kapsamında yoksullukla doğrudan ve dolaylı mücadele etmek üzere beytu'l-mal fonunu kullanmaktadır. İktisadi bir zulüm aracı olarak küresel bazda yoksulluğu derinleştiren faizi yasaklamaktadır.

Günümüz dünyasında yoksulluğu derinleştiren kapitalist iktisat anlayışı, geçmiş sosyalist tepkilere karşı sosyal devlet anlayışını kabullenmiştir. Ancak beşeri iktisat anlayışların aldığ1 tedbirlere rağmen, dünya genelinde yoksulluk problemi derinleştirmiştir. İslam iktisadı ise sosyal adaletin egemen olduğu bir iktisat düzenini ve insan onuruna layık yaşanabilir bir dünyayı hedeflemektedir. İslam iktisadı geçmişteki tecrübesiyle bunu ispatlamıştır. Aldığı önlemlerle bireyi, toplumu, insanlığ1 ve insanlık onurunu bu gün de koruyacak bir potansiyeldedir. 


\section{KAYNAKÇA}

Açıkgöz, Reşat - Yusufoğlu, Ö. Şükrü, “'Türkiye’de Yoksulluk Olgusu ve Toplumsal Yansimalar1", Insan ve Toplum Bilimleri Arasstrmalarn Dergisi, 1/1, (2012): 76-117.

Adnan Ertem, "Osmanlı'dan Günümüze Vakıf Medeniyeti", Vakıflar Dergisi, 36/1, (Aralık 1999): 25-65.

Amidî, Ali b. Ebi Ali b. Muhammed Seyfuddîn. el-İbkâm fî usûli'l-abkâm. Beyrut: Daru'l-Kutubi'l-'İlmiyye, 1999.

Asad Zaman. "An Islamic Approach to Inequality and Poverty". JKAU: Islamic Econ, 31/1, (January, 2018): 69-92.

Aydın, Nevzat. "Ahîlikte İş ve Ticaret Ahlakının Hz. Peygamber'in Sünnetindeki Temel Referansları", Bülent Ecevit Üniversitesi İlabiyat Fakültesi Dergisi, 2/1, (2015). 87-104.

Balta, Yusuf. "Belli Başlı Kaynaklarda Havaic-i Asliyye Listeleri”. Bülent Ecevit Üniversitesi ilahiyat Fakültesi Dergisi, 3/1, (2016). 227-239.

Bozan, Mahmut. "Yoksulluk Algısına Farklı Bir Bakış", Bartın Üniversitesi İ̈BF Dergisi, 8/15, (2017): 389-410.

Chossudovsky, Michel. 'Avlemetu'l-faker. Misır: Mektebetu İnsaniyyat 2012.

Cüveynî, Abdulmelik b. Abdullah b. Yusuf. “Ğıyasu'l-umem ve teyyasu'zzulem”. İskenderiye: Dâru'd-Da’ve, 1979.

Çayıroğlu, Yüksel. "İslam İktisadının Karakteristik Özellikleri”. İslam Hukuku Araștırmalar Dergisi, 24/1 (2014). 149-183.

Çizakça, Murat. Osmanl Dönemini Taribsel ve Ekonomik Boyutlar, https://www.tusev.org.tr/usrfiles/files/Osmanli_Donemi_Vakif larinin_Ekonomik_Boyutlari_(1).pdf, Erişim: 11.11.2019.

Daşlı, Yılmaz. "Yoksullukla Mücadelede Yeni Bir Yaklaşım: İşlevsel Yoksulluk" Turkish Studies, 13/26, (2018): 459-474.

Dımaşkî, Takıyuddin Ebubekir Muhammed b. Muhammed. Kifâyetu'labyâr fî halli ğayeti'l-ibtisâr. Beyrut, Dâru'l-Hayr, 2004.

Ebu Zekeriyya Muhyiddin Yahya b. Șeref en-Nevevî, el-Mecmû‘. Beyrut: Daru İhyai't-Turasi'l-'Arabî, tsz. 
Emrah Ayaşlıoğlu. Yoksulluk ve Reklam Algısı. Yüksek Lisans Tezi, Ankara Üniversitesi, 2007.

Eskicioğlu, Osman, "Fakr", TDV İslam Ansiklopedisi. Ankara: TDV Yay., 1995.

Fukuyama, Francis. Taribin Sonu ve Son Insan. İstanbul: Profil Yay., 2014.

Ğamravî, Muhammed Züheyr. Envâru'l-Mesâlik. Midyat: Dâru Nuri'sSabah, 2010.

Hareşî, Abdusselam. Fıkhu'l-fukarâi ve'l-mesâkîn. Beyrut, Dâru'l-Müeyyed, 2002.

http:/ / tuik.gov.tr/Start.do, Erişim: 31.01.2019.

https://www.unicefturk.org/yazi/GeertCappelaere, Erişim: 31.01.2019.

İbn Abidin, Muhammed Emin. Reddu'l-mubtâr 'ale'd-durrri'l-mubtâr. Beyrut: Dâru'l-F1kr, 2000.

İbn Aşur, Tahir. Mekasidu'ssşseriati'l-İslâmiyye. Dımaşk: Dâru'l-Kalem, 2016.

İbn Haldûn, Veliyuddin Abdurrahman b. Muhammed İbn Haldûn, elMukaddime. Dimaşk: Daru Ya'rûb, 2004.

İbn Hazm, Ebu Muhammed Ali b. Ahmed b. Said. el-Muhalla. Beyrut: Dâru'l-Kutubi'l-'İlmiyye, 2010.

İbn Hazm, Ebu Muhammed Ali b. Ahmed b. Said. el-Muhalla. Beyrut: Dâru'l-Kutubi'l-'İlmiyye, 2010.

İbn Hibban Muhammed b. Ahmed. Sabîhu İbn Hıbbân. Beyrut: Müessesetu'r-Risâle, 1993.

İbn Hümam, Kemâluddîn Muhammed b. Abdulvahid. Fethu'l-kadîr. Beyrut: Dâru'l-Kutubi'l-'İlmiyye, 2003).

İbn Kudâme, Muvaffakuddin Abdullah b. Ahmed. eş-Şerhu'l-kebîr. Beyrut: Dâru'l-F1kr 2011.

İbn Manzur, Cemâlüddîn Muhammed b. Mükerrem b. Alî b. Ahmed. Lisânu'l-'Arab. Kahire: Daru'l-Me'arife, Tsz.

İbn Rüşd, Muhammed b. Ahmed b. Muhammed b. Ahmed. Bidâyetu'lmüctehid. Beyrut: Dâru'l-Kutubi'l-'İlmiyye, 2007.

Karadaği, Muhyiddin Ali. el-Medhal ila iktisâdi'l-İslamî. Beyrut: Daru'lBeşâiri'l-İslamiyye, 2010. 
Karadâvî, Yusuf. Flkhu'ž-žekât. Beyrut: Müessesetu'r-Risâle, 2011.

Karadavi, Yusuf. Muskiletu'l-faker ve keyfe 'alecehe'l-Islam. Beyrut: Müessesetu'r-Risâle, 1985.

Karaman, Hayrettin. İslam Ticaret İlmihali. İstanbul: İz Yayınc1lık, 2012.

Kâsânî, Ebubekir b. Mes'ud b. Ahmed. el-Bedain's-sanầ fì tertîbi'şşerayi :Beyrut: Dâru İhyai't-Turâsi'l-'Arabî, 1998.

Kutup, Seyyid. İslam'in Dünya Görïşü. İstanbul: Arslan Yayınları, 1991.

Köse, Saffet. Genetiğiyle Oynanmıs Kavramlar ve Aile Medeniyetinin Sonu. Konya: Mehir Vakf1 Yayınları, 2015.

Lucas, Robert. "Expectations and the Neutrality of Money", Journal of Economic Theory, 4/1, (1972): 103-124.

Macit, Mustafa. "Yoksulluk İnsan Onuru ve Din", Atatürk Üniversitesi İlabiyat Fakültesi Dergisi, 41/1, (2014): 102-116.

Misrî, Refik Yunus. Usûlu İktisâdi'l-İslâmî. Beyrut, Daru'ş-Şamiyye, 2012.

Nassâr, Ahmed Muhammed Mahmud. Mebâdiu iktisadi'l-Islamî. Beyrut: Dâru'n-Nefâis, 2010.

Nebhânî, Takıyuddin. en-Nizâamu'l-iktisadî fi'l-İslam. Beyrut: Dâru'l-Umme, 2004.

Orhan, Serdar- Savuk, Fatih. "Emek Teknoloji İşsizlik İlişkisi”, CSGB Çalşma Dünyası Dergisi, 2/2, (Ağustos, 2014): 9-24.

Osmanî, Muhammed Takıyuddin. Usûlu'l-iftâ ve âdâbubu. Dımaşk, Dâru’lKalem, 2014.

Öztürk, Yaşar Nuri. Kur'an ve Sünnete Göre Tasavvuf. İstanbul, Yeni Boyut Yay., 1998.

Râzî, Muhammed b. Ömer. Mefâtibu'l-ğayb. Beyrut: Dâru İhyai'-t-Turâsi'l'Arabî, Tsz.

Sami, Şemsettin. Kamûs-ı Türkê. İstanbul, Çağrı Yayınları, 1996.

Şafîi, Muhammed b. İdris. er-Risale. Beyrut: Daru'l-Kutubi'l-İlmiyye, 2005. 
Şenses, Fikret. Küreselleşmenin Öteki Yü̈ü Yoksulluk. İstanbul, İletişim Yay., 2009.

Tabakoğlu, Ahmet. "Bir İlim Olarak İslam İktisadı", İslam Hukuku Arasturmalar Dergisi, 16/1, (2010): 11-34.

Tabakoğlu, Ahmet. İslami İlimlerde Usul/Metodoloji Meselesi II, İstanbul: İslami İlimler Araştırma Vakfı, 2005.

Taberî, Muhammed b. Cerîr. Camiu'l-Beyân fî̀ Te'vîli'l-Kur'ân, (Beyrut, Müessesetu'r-Risâle, 2000

Taş, Yunus- Özcan, Selami. “Türkiye'de ve Dünya'da Yoksulluk Üzerine Bir Araştırma”, International Conference On Eurasian Economies, (2012): 423-430.

Tireli, Münir. Küreselleşme ve Yoksulluk: Birlesmiş Milletle ve Dünya Bankası Göstergeleri Işı̆ğnda Bir Analiæ. Uzmanlık Tezi, Ankara, 2009.

Uçar, Ramazan Gürsel. Düsünmeye Akletmeye Davet. İstanbul: Mevsimler Kitap, 2018.

Uludağ, Süleyman. Kuşeyrî Risalesi. İstanbul: Dergâh Yay., 1999.

Usame Sadık Tayyib-Abdullah b. Ömer-Isam b. Yahya Fîlâlî. Mukâfehatu'l-fakr. Cidde, Merkezu'l-İntâci'l-I'lâmî, 2006.

Widiyanti, Dwi Retno. "Redistribution Adjusts Efficiency In Economy; Islamic Paradigm" Global Journal of Business and Social Science Review, 3/1, (Nowember 2015): 2-9.

Yaman, Ahmet - Çalış, Halit. İslam Hukuku. Ankara: Bilay Yayınları, 2018.

Yllmaz, Kamil. Tasavvuf ve Tarikatlar. İstanbul, Ensar Yay., 2007.

Zemahşerî, Ebu'l-Kasım Mahmûd b. Ömer b. Muhammed. Esâsu'lBelâğa. Beyrut: Dâru İhyai't-Turâsi'l-'Arabî, 2001.

Zerkâ, Muhammed Enes b. Mustafa. Sünaìyetu mesâdiri'l-ma'rife fì 'ilmi'liktısadil-İslamî ve netâicuha'l-menhecìyye. Cidde: Kral Abdulaziz Üniversitesi Yay. Tsz. 